\title{
Ostracods as ecological and isotopic indicators of lake water salinity changes: the Lake Van example
}

\author{
Jeremy McCormack ${ }^{1}$, Finn Viehberg ${ }^{2,3}$, Derya Akdemir ${ }^{2}$, Adrian Immenhauser $^{1}$, and Ola Kwiecien ${ }^{1}$ \\ ${ }^{1}$ Institute for Geology, Mineralogy \& Geophysics, Ruhr University Bochum, Universitätsstraße 150, \\ 44801 Bochum, Germany \\ ${ }^{2}$ Institute for Geology and Mineralogy, University of Cologne, Zülpicher Straße 49A, 50674 Köln, Germany \\ ${ }^{3}$ Institute for Geography und Geology, University of Greifswald, Friedrich-Ludwig-Jahn Str. 16, 17487 Greifswald, Germany
}

Correspondence: Jeremy McCormack (jeremy.mccormack@rub.de)

Received: 6 November 2018 - Discussion started: 2 January 2019

Revised: 21 March 2019 - Accepted: 29 April 2019 - Published: 20 May 2019

\begin{abstract}
Ostracods are common lacustrine calcitic microfossils. Their faunal assemblage and morphological characteristics are important ecological proxies, and their valves are archives of geochemical information related to palaeoclimatic and palaeohydrological changes. In an attempt to assess ostracod ecology (taxonomic diversity and valve morphology) combined with valve geochemistry $\left(\delta^{18} \mathrm{O}\right.$ and $\delta^{13} \mathrm{C}$ ) as palaeosalinity indicators, we analysed sedimentary material from the International Continental Scientific Drilling Program (ICDP) Ahlat Ridge site from a terminal and alkaline lake, Lake Van (Turkey), covering the last 150 kyr. Despite a low species diversity, the ostracod faunal assemblage reacted sensitively to changes in the concentration of total dissolved salts in their aquatic environment. Limnocythere inopinata is present throughout the studied interval, while Limnocythere sp. A is restricted to the Last Glacial period and related to increased lake water salinity and alkalinity. The presence of species belonging to the genus Candona is limited to periods of lower salinity. Valves of Limnocytherinae species (incl. L. inopinata) display nodes (hollow protrusions) during intervals of increased salinity. Both the number of noded valves and the number of nodes per valve appear to increase with rising salinity, suggesting that node formation is related to hydrological changes (salinity and/or alkalinity). In contrast to Lake Van's bulk $\delta^{18} \mathrm{O}$ record, the $\delta^{18} \mathrm{O}$ values of ostracod valves do record relative changes of the lake volume, with lower values during high lake level periods. The $\delta^{13} \mathrm{C}$ values of different species reflect ostracod habitat preferences (i.e. infaunal vs. epifaunal) but are less sensitive to hydrological changes. However, combined with
\end{abstract}

other proxies, decreasing Holocene $\delta^{13} \mathrm{C}$ values may indicate a freshening of the lake water compared to the low lake level during the Last Glacial period. The Lake Van example underscores the significance and value of coupling ostracod ecology and valve geochemistry in palaeoenvironmental studies of endorheic lake basins.

\section{Introduction}

The water volume of closed lakes (endorheic basins) in arid and semi-arid regions reacts particularly sensitively to climatically induced changes in the ratio of meteoric precipitation to evaporation $(\mathrm{P} / \mathrm{E})$. When the lake volume decreases, the concentration of solutes increases (e.g. Dana and Lenz, 1986; Aladin and Potts, 1992), and consequently (pore)water salinity is a conservative tracer of past climate fluctuations (Tomonaga et al., 2017). Yet, porewater salinity profiles have a relatively low resolution and record only major changes at millennial timescales. Palaeoecological (e.g. faunal assemblage, phenological and morphological variation) and geochemical (e.g. biomarker, carbonate trace elemental and isotope geochemistry) salinity proxies offer higher temporal resolution but are, by definition, indirect indicators. In nonmarine environments, calcitic valves of ostracods (benthic, bivalve Crustacea) are established biological proxies to infer past environmental conditions from species ecological tolerance, morphometry and/or valve geochemistry. Numerous previous studies exemplified the application of ostracod valves in tracking past hydrological changes (e.g. Van der 
Meeren et al., 2010, 2011; Decrouy, 2012; Smith and Palmer, 2012; Horne et al., 2012; Viehberg et al., 2012; Meyer et al., 2016).

The composition of an ostracod assemblage is influenced by several factors such as the type of surface sediment, ambient water temperature, dissolved oxygen concentration and salinity (Holmes et al., 2010; Mesquita et al., 2012; Ruiz et al., 2013). Concerning salinity, not only the concentration of total dissolved ions (De Deckker, 1981; Aladin and Potts, 1996) but also the ionic composition of the water controls the diversity of ostracod assemblages (Forester and Brouwers, 1985; Smith, 1993). Based on species-specific tolerances and optima towards salinity and water chemistry, ostracod assemblages are valuable palaeosalinity indicators (e.g. Boomer et al., 2003; Keatings et al., 2010).

Several authors related a variety of morphological changes of the hard parts (single valves or complete carapaces) of the same ostracod species to changing salinity. Rosenfeld and Vesper (1977) observed an inverse relationship between the roundness of sieve pores of the species Cyprideis torosa (Jones, 1850) and salinity. The valve length or length / height ratio of some species, e.g. Mytilocypris henricae (Chapman, 1966), C. torosa and Limnocythere inopinata (Baird, 1843) seem to be salinity-dependent (Martens, 1985; Neale, 1988; Van de Meeren et al., 2010). The most easily recognisable morphological change related to salinity is the development of a distinct type of ornamentation on the valves' lateral surface expressed as hollow, typically round protrusions termed "nodes" (Kilenyi, 1972; van Harten, 2000; Keyser, 2005). Among the species developing these nodes, most research focussed on the brackish species C. torosa (e.g. Kilenyi, 1972; Vesper, 1975; van Harten, 2000), which is presumed to produce more nodes and prominent nodes with decreasing salinity (Keyser, 2005; Frenzel et al., 2012).

In addition, by means of their calcite valves, ostracods have the potential to reinforce palaeoecological and palaeoenvironmental implications by using a geochemical approach (Smith and Palmer, 2012). The ratios of trace elements to calcium, primarily $\mathrm{Sr} / \mathrm{Ca}$ and $\mathrm{Mg} / \mathrm{Ca}$, often covary positively with salinity (Holmes, 1996; Holmes and De Deckker, 2012). However, other factors, not necessarily salinity-related, such as increased inorganic carbonate precipitation and mineralogy, water temperature, $\mathrm{Mg}$ concentration and/or alkalinity of the ambient water may also affect $\mathrm{Sr} / \mathrm{Ca}$ and $\mathrm{Mg} / \mathrm{Ca}$ ratios of ostracod valves (e.g. Engstrom and Nelson, 1991; De Deckker et al., 1999; Bahr et al., 2009; Zhang et al., 2009; Gouramanis and De Deckker, 2010). The oxygen isotope composition $\left(\delta^{18} \mathrm{O}\right)$ of ostracod valves is a function of the temperature and the isotopic composition of the lake water in which the biominerals were secreted, modified by a vital offset, a systematic, species-specific deviation from the $\delta^{18} \mathrm{O}$ value of a theoretical calcite precipitated under equilibrium conditions (von Grafenstein et al., 1999, Decrouy, 2012). The carbon isotopic composition $\left(\delta^{13} \mathrm{C}\right)$ of an ostracod valve reflects the $\delta^{13} \mathrm{C}$ of the dissolved inorganic carbon $\left(\delta^{13} \mathrm{C}_{\mathrm{DIC}}\right)$ at the time of moulting (von Grafenstein et al., 1999; Keatings et al., 2002). Three processes control the lake water $\delta^{13} \mathrm{C}_{\mathrm{DIC}}$ : (i) biological activity in the lake, (ii) atmosphere-water $\mathrm{CO}_{2}$ exchange and (iii) the $\delta^{13} \mathrm{C}_{\mathrm{DIC}}$ of inflowing water (Kelts and Talbot, 1990; Leng and Marshall, 2004). Often, and in combination with other proxies, increasing $\delta^{13} \mathrm{C}_{\text {ostracod }}$ values have been interpreted in terms of a decreasing lake volume, associated with lower freshwater input and enhanced productivity (e.g. von Grafenstein et al., 2000; Frogley et al., 2001; Edwards et al., 2006).

Here we take advantage of Lake Van's well-constrained palaeoenvironmental conditions (Litt and Anselmetti, 2014, and references therein) and test the versatility of ostracods as salinity indicators in an endorheic lake basin. We juxtapose changes in ostracod taxonomy, valve morphology (noding) and oxygen $\left({ }^{18} \mathrm{O}\right)$ and carbon $\left(\delta^{13} \mathrm{C}\right)$ isotopic composition for the last $150 \mathrm{kyr}$ (International Continental Scientific Drilling Program, ICDP, Ahlat Ridge site) with independent low-resolution salinity proxies including biomarker indicators (Randlett et al., 2017) and directly measured porewater salinity (Tomonaga et al., 2017). Further, we document the variability in the valve isotopic composition of three concurrent ostracod taxa and identify their ecology-related controlling mechanisms. Finally, we compare the isotopic data of ostracod valves and of inorganic carbonates (calcite and aragonite; McCormack et al., 2019a) with proxy records for relative changes in the $\mathrm{P} / \mathrm{E}$ ratio including arboreal pollen percentage (Litt et al., 2014; Pickarski et al., 2015a, b), the XRF Ca / K ratio (Kwiecien et al., 2014), lithology and total organic carbon content (TOC; Stockhecke et al., 2014a). We expect that, while the mixed nature of the inorganic carbonates (McCormack et al., 2019a) masks the response of their isotopic composition to salinity changes, the biogenic carbonate mirrors these changes with a higher fidelity.

\section{Limnological setting and state of the art of Lake Van}

Lake Van is a terminal, alkaline lake in Eastern Anatolia, Turkey, situated on a high plateau with a lake level today at an altitude of $1648 \mathrm{~m}$ above sea level (Litt and Anselmetti, 2014). Its alkaline nature, characterised by near-equal shares of sodium carbonate and sodium chloride, is a result of the volcanic hinterland and high evaporation rates (Kempe et al., 1991; Reimer et al., 2009). The lake's total alkalinity reaches ca. $151 \mathrm{mmol} \mathrm{L}^{-1}$, salinity ca. $22 \mathrm{~g} \mathrm{~kg}^{-1}$ and $\mathrm{pH} 9.7-$ 9.8 (Kempe et al., 1991; Reimer et al., 2009; Litt et al., 2012). The $\mathrm{Mg}^{2+}$ concentration in the water is low, whereas $\mathrm{Ca}^{2+}$ is strongly depleted (Kempe et al., 1991; Reimer et al., 2009), and its concentration decreases further below the epilimnion due to the precipitation of carbonate minerals in the surface water (Landmann et al., 1996; Reimer et al., 2009; Stockhecke et al., 2012).

The recovery of a continuous $220 \mathrm{~m}$ long sedimentary succession in Lake Van in 2010 supported by the ICDP greatly 
expanded our knowledge about the evolution of the lake itself and the environmental changes in the Near East over the last $\sim 600000$ years (Litt and Anselmetti, 2014). Several independent proxy records including palynological, XRF Ca / K ratios, total organic carbon content (TOC) and lithology show a mostly coherent palaeoclimate signal, involving wetter interglacials with a higher lake level and more arid glacial periods with a generally lower lake level (Kwiecien et al., 2014; Litt et al., 2014; Stockhecke et al., 2014; Pickarski et al., 2015a, b). A generally lower lake level between ca. 80 and $30 \mathrm{ka}$ is also implied from biomarker salinity proxies and direct porewater measurements (Randlett et al., 2017; Tomonaga et al., 2017), with the maximum salinity (ca. 50 to $80 \mathrm{~g} \mathrm{~kg}^{-1}$ ) reached during a lowstand between 30 and $14 \mathrm{ka}$ and a lake level ca. $200 \mathrm{~m}$ lower than present (Stockhecke et al., 2014a; Tomonaga et al., 2017). Seismic profiles reveal palaeoshorelines and geomorphological features supporting this lowstand (Cukur et al., 2014a, b). Similar lower lake levels and more arid late glacial conditions are also documented from other lakes in the vicinity such as Lake Xinias (Digerfeldt et al., 2000) and Lake Urmia (Stevens et al., 2012). On the contrary, the glacial Dead Sea lake level is assumed high (Dor et al., 2018), highlighting the complex spatial pattern of hydrological variability during the last glacial-interglacial cycle in the eastern Mediterranean, which is a matter of a long-lasting debate (see reviews in Tzedakis, 2007, and Jones et al., 2019)

An array of independent proxy records (e.g. Kwiecien et al., 2014; Stockhecke et al., 2014a; Pickarski et al., 2015b; McCormack et al., 2018) have demonstrated a high sensitivity of Lake Van and its catchment to Northern Hemisphere temperature oscillations, in particular to Greenland Stadials and Interstadials, dubbed Dansgaard-Oeschger cycles. Interstadials contrast typical glacial and/or stadial conditions and are characterised by higher moisture availability in the Lake Van area (Pickarski et al., 2015b), resulting in a rising lake level and the deposition of finely laminated sediments (Stockhecke et al., 2014a).

The bulk carbonate $\delta^{18} \mathrm{O}$ record $\left(\delta^{18} \mathrm{O}_{\text {bulk }}\right)$ is at odds with the other proxy records recovered from the 2010 ICDP coring, with higher values appearing in both cold arid periods such as the Younger Dryas and in warm wet periods such as the Last Interglacial (MIS 5e; Kwiecien et al., 2014). McCormack et al. $(2018,2019 a)$ have shown that the bulk carbonate fraction consists of variable amounts of different carbonate mineral phases, primary low-Mg calcite and aragonite and early diagenetic calcian dolomite. Further, these authors argue that surface water carbonates (calcite and aragonite) differ isotopically from each other due to their precipitation in close-to-freshwater and evaporative concentrated lake water, respectively. Consequently the isotopic composition of the bulk carbonate is biased towards the composition of the most abundant inorganic carbonate fraction. Ostracod valves, relatively easy to separate from the inorganic fraction, provide an independent and in the case of Lake Van hitherto unexplored palaeoenvironmental archive/proxy. Although the episodic presence of turbidite layers in the sediment cores implies periodical transport of allochthonous material to the site (Stockhecke et al., 2014a), the presence of ostracod valves in finely laminated undisturbed (varved) sediments and their generally excellent preservation suggest an autochthonous deposition or, if any, then a very short transport.

\section{Material and methods}

This study was carried out on material recovered in 2010 in the framework of the ICDP PALEOVAN. We resampled $2 \mathrm{~cm}$ thick intervals from the Ahlat Ridge composite profile and off-sections, avoiding the sampling of event deposits. Composite profile depth (and age; Stockhecke et al., 2014b) was assigned to off-section samples by visual correlation based on high-resolution core images. The data presented here comprise 256 samples. Sampling range covers the uppermost $68 \mathrm{~m}$ ( $56 \mathrm{~m}$ without event deposits) of the composite profile, corresponding to $147.8 \mathrm{ka}$, with a mean temporal resolution of 54 years per sample. Sediment samples were wet-sieved into three fractions ( $>250,250-125$, $125-63 \mu \mathrm{m})$, rinsed with distilled water and air-dried. Ostracod valves were picked and counted from the $>250$ and 250-125 $\mu \mathrm{m}$ fractions under a stereomicroscope and stored in microfossil slides. The identification of ostracod valves was based on morphological characteristics and verified with regional and standard identification keys and taxonomic reports (Suzin, 1956; Bubikjan, 1966, 1984; Meisch, 2000; Wilkinson et al., 2005; Karanovic, 2012; Külköylüoğlu et al., 2012; Danielopol et al., 2018), using a high magnification of the stereomicroscope and scanning electron microscope. The diverse limnocytherid fauna will be the subject of an additional paper (McCormack et al., 2019b); however, the geochemical studies focus on the dominant species of the fossil record (Limnocythere inopinata, Limnocythere sp. A and Candona sp.; Fig. 1). For statistical assemblage analyses (relative taxonomic abundance), only samples with more than 20 ostracod valves were taken into account; similarly cumulative statistics regarding noding are based on samples with at least 20 limnocytherid valves (excluding Limnocythere sp. A, which never features nodes). Only well-preserved valves, i.e. translucent, well calcified and mostly intact, were counted. SEM images were taken from gold-sputtered samples using a Leo/Zeiss Gemini 1530 as well as a Gemini 2 - Merlin, both operating with an acceleration voltage of $20 \mathrm{kV}$.

After careful visual inspection with the stereomicroscope, only clean (fully translucent, without any foreign matter) valves were used for isotopic analyses. If necessary valves were manually cleaned using a fine brush and distilled water to remove artefacts. Isotopic analyses were carried out on adult and juvenile Limnocythere inopinata, Limnocythere sp. A and Candona sp. valves for samples with a sufficient number of valves in a pristine state. Size range and sex of 


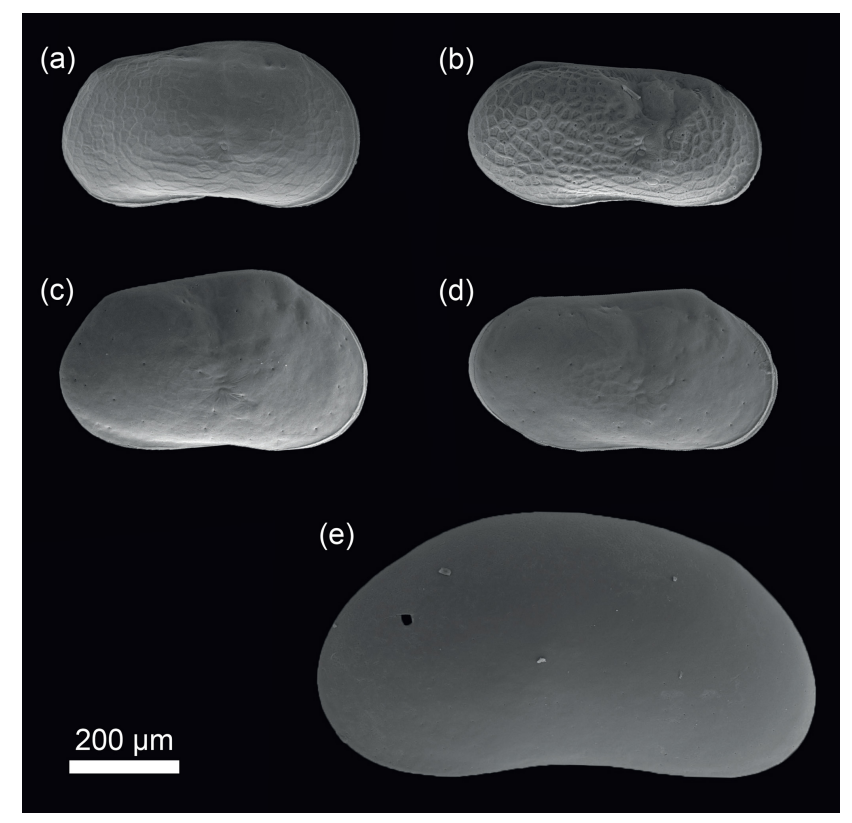

Figure 1. SEM photographs of the external lateral views of key species used in this study. (a) Female right valve Limnocythere inopinata, (b) male right valve Limnocythere inopinata, (c) female right valve Limnocythere sp. A, (d) male right valve Limnocythere sp. A and (e) female left valve Candona sp.

the valves were noted for each sample to estimate potential influences of ontogeny and sex on valve isotopy. Ostracod valve length was determined using the image software ZEN 2.3 lite based on digital stereomicroscope photographs, taken with a Zeiss Axiocam 105 colour camera attached to a Stemi 508 stereomicroscope. Length measurement errors were determined using repeated length measurements (10 times) for five different valves, yielding a maximum standard deviation of $3.2 \mu \mathrm{m}$. For isotope measurements of the genus Candona sp., large clearly identified fragments, as well as valves from samples with fewer than 20 valves, were also analysed.

Oxygen and carbon isotope ratios $\left(\delta^{18} \mathrm{O}\right.$ and $\left.\delta^{13} \mathrm{C}\right)$ were determined on a Thermo Scientific Kiel IV carbonate device coupled to a MAT253Plus mass spectrometer at the Ruhr University Bochum. A total of 140 measurements, including replicate analyses, were performed on samples from the Ahlat Ridge ICDP site, as well as four measurements on samples from a short gravity core (Van12-08, 53 to $31 \mathrm{~cm}$ below the lake floor). The gravity core was retrieved at the Ahlat Ridge site in May 2012, and its material complemented the late Holocene sedimentary record of the Ahlat Ridge composite profile. Between 15 and $60 \mu \mathrm{g}$ of ostracod carbonate was weighed into Kiel reaction vials and reacted at $70^{\circ} \mathrm{C}$ in orthophosphoric acid $\left(105 \% \mathrm{H}_{3} \mathrm{PO}_{4}\right)$. Depending on valve size and thickness, between 2 and 68 valves were measured. Results are reported in permil (\%o) in the common delta notation. Raw data were corrected using the standard ISOA (Bernasconi et al., 2018) and the international standards
NBS-19, IAEA-603 and CO-8. Final isotope ratios are normalised against the Vienna PeeDee Belemnite (V-PDB) standard. The external standard deviation of repeated analyses is $<0.05 \%$ for both $\delta^{13} \mathrm{C}$ and $\delta^{18} \mathrm{O}$.

\section{Results}

\subsection{Ostracod taxonomy and morphology}

The three dominant taxa, Limnocythere inopinata, Limnocythere sp. A and Candona sp., were identified (Fig. 1). L. inopinata is present throughout the studied sediment sequence with both valves of females and males, implying the presence of a sexual population (Figs. 1,2). Limnocythere sp. A also occurs as a sexual population but clearly differs from $L$. inopinata and other Limnocytherinae species from its general outline and morphologic texture (Fig. 1). Limnocythere sp. A generally dominates the faunal assemblage, contributing up to $98 \%$ to the relative ostracod composition (mean $=63 \%$ ) between 36.2 and $5.2 \mathrm{~m}$ composite below lake floor (mcblf) corresponding to 81.0 to $12.2 \mathrm{ka}$. Valves of the genus Candona were not further differentiated herein. Candona sp. contributes up to $43 \%$ to the relative ostracod composition (mean $=5 \%$ ), occurring only at depths between 67.6 and 50.9 mcblf, corresponding to an age between 147.9 and $108.9 \mathrm{ka}$.

The valves of polymorphic Limnocytherinae species show varying reticulation and valve morphometrics. Here we focus on the most noticeable morphological variation, the appearance of hollow protrusions (nodes) with different intensity (number of nodes and size) and shape (round, spinous). The highest number of noded valves appears between ca. 73 and 35,30 and 12 and 11 and $3 \mathrm{ka}$, with mean percentages of noded valves of $64 \%, 43 \%$ and $57 \%$, respectively (Fig. 3). Intervals with very low numbers of noded valves at ca. 148$137,137-105$ and 3-0 ka have mean percentages of noded valves of $4 \%, 1 \%$ and $3 \%$ respectively. One sample dated at ca. $137 \mathrm{ka}$ has $31 \%$ noded valves, and the interval between 105 and $75 \mathrm{ka}$ is characterised by valves with highly varying amounts of noding between $0 \%$ and $47 \%$ (Fig. 3). Among the noded valves from the Holocene, most valves only have one node (Fig. 3). Three noded valves dominate the period of ca. $73-35 \mathrm{ka}$, with a mean of $45 \%$ of valves with three or more nodes. Nodes from the Holocene are typically smaller and round and are documented on Limnocythere inopinata valves, whereas those from the Last Glacial period are commonly larger and often spinous (Fig. 4).

\subsection{Ostracod valve oxygen and carbon isotopy}

The isotopic composition of valves varies for both $\delta^{18} \mathrm{O}$ and $\delta^{13} \mathrm{C}$ between different species (Table 1). Geochemical data from valves belonging to the same species, sex, reticulation intensity and size range, within one sample, generally show a mean isotopic variability on the order of up to $0.6 \%$ only 

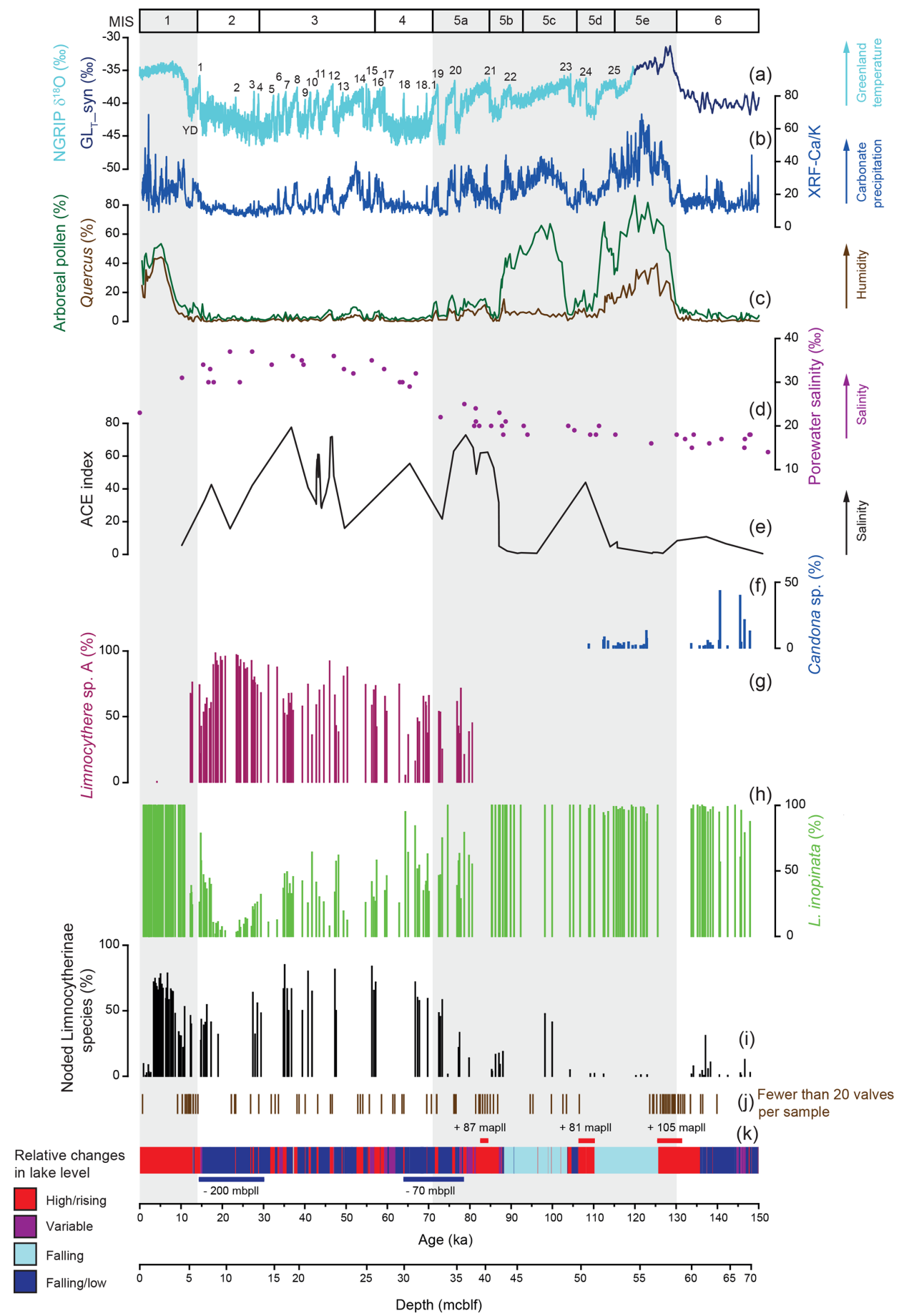

Figure 2. Relative distribution of ostracod taxa in Lake Van in comparison to various palaeoenvironmental proxy records. (a) Isotopic composition of the NGRIP ice core (NGRIP, 2004; Steffensen et al., 2008; Svensson et al., 2008; Wolff et al., 2010) and a synthetic Greenland

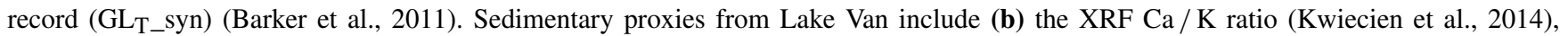
(c) arboreal pollen and Quercus pollen percentage (Litt et al., 2014; Pickarski et al., 2015a, b; Pickarski and Litt, 2017), (d) porewater salinity plotted against depth in metres' composite below lake floor (mcblf; Tomonaga et al., 2017), (e) biomarker Archaeol and Caldarchaeol Ecometric (ACE) index (Randlett et al., 2017) and (k) lithologies with genetic interpretations related to lake level variability as a coloured bar (simplified according to Stockhecke et al., 2014a) and major lake level variations (Stockhecke et al., 2014a; Tomonaga et al., 2017) in metre above/below present lake level (mapll/mbpll). (f-h) Relative abundance of ostracod taxa. (f) Candona sp., (g) Limnocythere sp. A and (h) Limnocythere inopinata. (i) Percentage of noded Limnocytherinae species. (j) Position of samples containing fewer than 20 valves; these samples were not included in the statistical assemblage analyses. The grey shaded areas represent interglacials. 


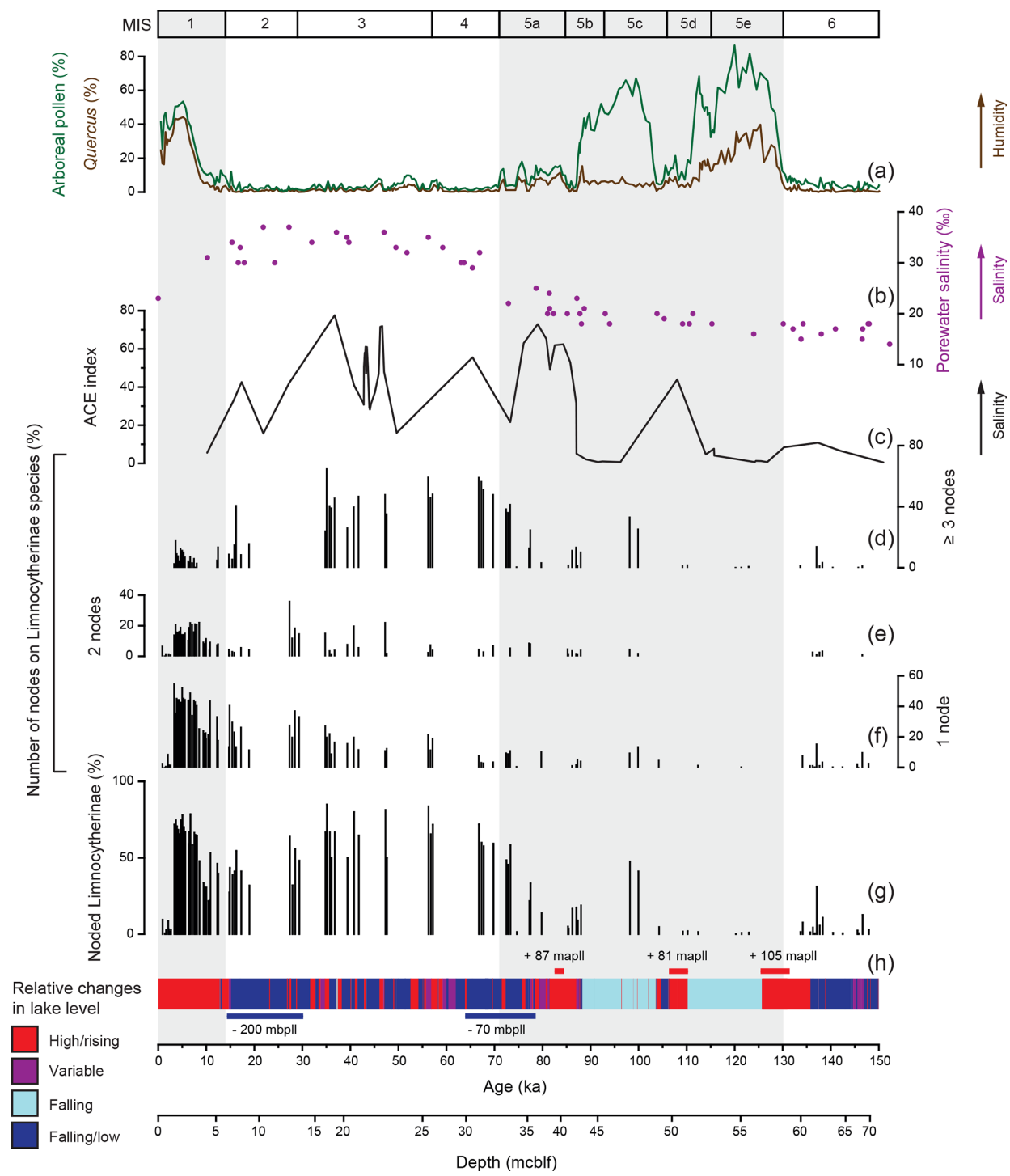

Figure 3. Amount and number of noded Limnocytherinae species valves relative to Lake Van palaeoenvironmental proxy records. Sedimentary proxies from Lake Van include (a) arboreal pollen and Quercus pollen percentage (Litt et al., 2014; Pickarski et al., 2015a, b; Pickarski and Litt, 2017), (b) porewater salinity plotted against depth in metres' composite below lake floor (mcblf; Tomonaga et al., 2017), (c) biomarker Archaeol and Caldarchaeol Ecometric (ACE) index (Randlett et al., 2017) and (h) lithologies with genetic interpretations related to lake level variability as a coloured bar (simplified according to Stockhecke et al., 2014a) and major lake level variations (Stockhecke et al., 2014a; Tomonaga et al., 2017). (d-f) Number of nodes in percent. (g) Total percentage of noded Limnocytherinae species. The grey shaded areas represent interglacials.

(Fig. 5a; Table 1). Geochemical data from L. inopinata valves of different reticulation intensity, size range and sex showed no consistent differences in $\delta^{18} \mathrm{O}$ and $\delta^{13} \mathrm{C}$ that could be related to either of these factors (Fig. 5a-c). Co-occurring smooth and reticulated valves of $L$. inopinata dated between 137 and $117 \mathrm{ka}$ have a $\delta^{18} \mathrm{O}$ difference of up to $0.4 \%$, while only one sample shows smooth valves with $1.9 \%$ o higher values compared to the more reticulated valves (Table 1). The valves of Limnocythere sp. A are with one exception continuously higher in both $\delta^{18} \mathrm{O}$ and $\delta^{13} \mathrm{C}$ compared to L. inopinata, from the same stratigraphic horizon, by $0.4 \%$ to $2.9 \%$ and
$0.4 \%$ o to $1.3 \%$ respectively (Fig. 5 d, e). Candona sp. valves from the same sample have constantly $0.4 \%$ o to $0.9 \%$ higher $\delta^{18} \mathrm{O}$ values and $2 \%$ o to $6 \%$ lower $\delta^{13} \mathrm{C}$ values than those of L. inopinata (Fig. 5d, e). 

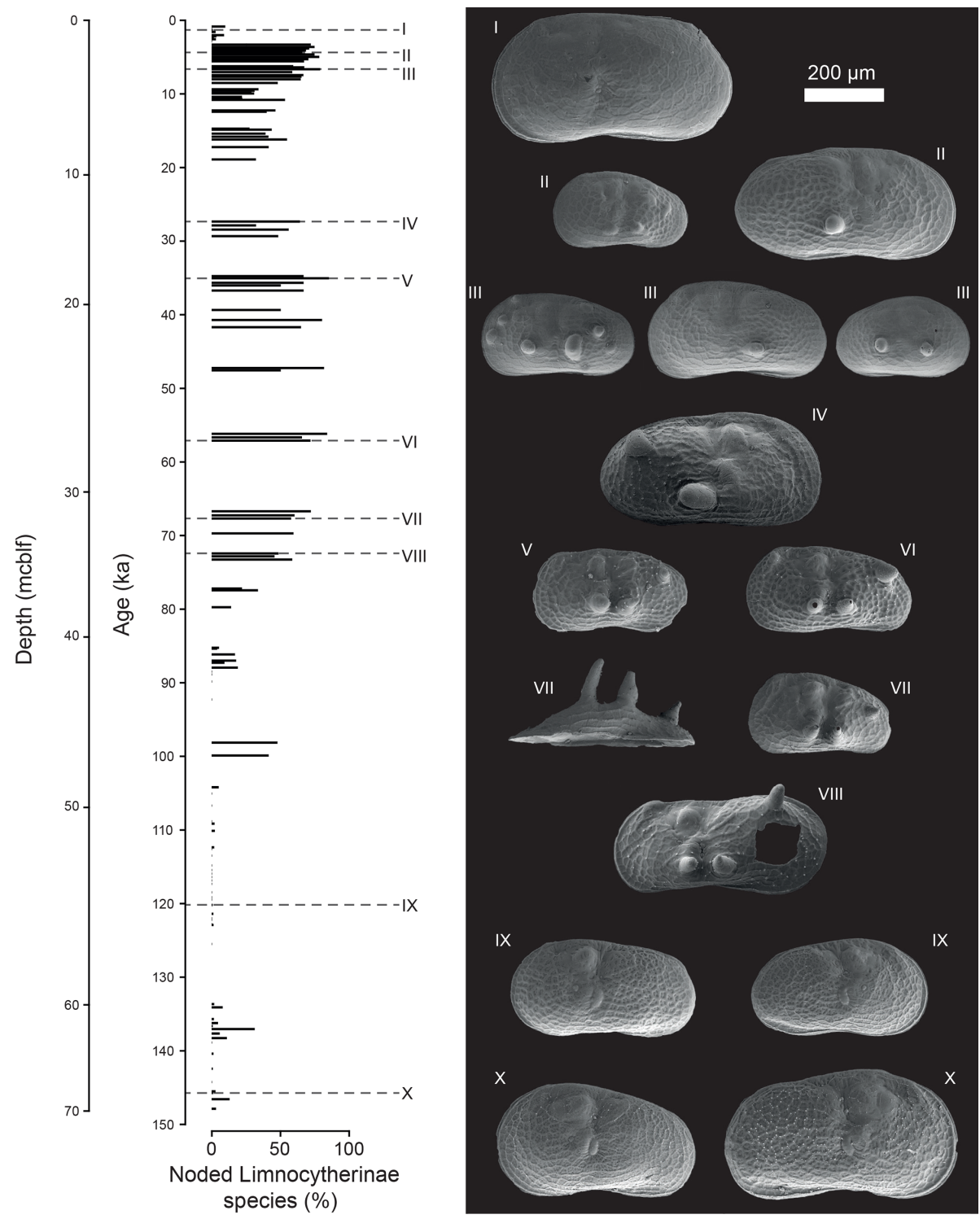

Figure 4. Illustration of number and intensity of noded Limnocytherinae species valves (as SEM images) within the studied interval. Roman numerals indicate the depth and age of individual valves. The valves displayed here are both from adult and juvenile ostracods.

\section{Discussion}

\subsection{Ostracod taxonomy and morphology as palaeosalinity proxies}

\subsubsection{Variations in relative species abundance}

In the sample material studied, the taxonomic diversity is relatively low, as expected from a saline lake with low $\mathrm{Ca}^{2+}$ concentrations (De Deckker and Forester, 1988; McCormack et al., 2019b). Only L. inopinata is found throughout the profile. L. inopinata tolerates high alkalinity (Meisch, 2000 ) and a high salinity range (ca. $0-50 \mathrm{~g} \mathrm{~kg}^{-1}$ ), favouring a $\mathrm{Na}^{+}-\mathrm{HCO}_{3}^{-}-\mathrm{CO}_{3}^{2-}$-rich and $\mathrm{Ca}^{2+}$-depleted water composition (Forester, 1983, 1986; Neale et al., 1988; Smith,
1993; Holmes et al., 1999; Li et al., 2010). The presence of $L$. inopinata throughout the profile suggests a close-toconstant $\mathrm{Na}^{+}-\mathrm{HCO}_{3}^{-}-\mathrm{CO}_{3}^{2-}$-rich water composition and is in agreement with a close-to-steady-state relative proportion of most ions indicated by porewater analyses (Tomonaga et al., 2017).

Species belonging to the genus Candona sp. are typically associated with lower salinities (ca. $0-15 \mathrm{~g} \mathrm{~kg}^{-1}$; e.g. De Deckker, 1981; Anadón et al., 1986; Neale, 1988; Forester, 1991; Li et al., 2010). Candona (Fabaeformiscandona) rawsoni (Tressler, 1957), for example, is mainly documented in alkaline lakes with low water salinity but can also be found in lakes with higher salinity and less alkaline conditions (Forester, 1986). In Lake Van, Candona sp. valves occur in 
Table 1. Isotopic variability (minimum, maximum and mean) between different species, sex, valve size and reticulation intensity from the ICDP Ahlat Ridge cores. For six samples, replicate analyses were performed with valves showing no differentiating characteristics. Calculated variance is represented by the difference of these replicate analyses. Analyses comparing sex, valve size and reticulation intensity were measured from the same stratigraphic horizon. $n$ represents the number of measurements.

\begin{tabular}{|c|c|c|c|c|c|c|c|}
\hline \multirow[b]{2}{*}{ Analyses } & \multirow[b]{2}{*}{$n$} & \multicolumn{3}{|c|}{$\delta^{18} \mathrm{O}$} & \multicolumn{3}{|c|}{$\delta^{13} \mathrm{C}$} \\
\hline & & Minimum & Maximum & Mean & Minimum & Maximum & Mean \\
\hline Replicate analyses' variance & 12 & 0.0 & 0.5 & 0.2 & 0.1 & 0.5 & 0.2 \\
\hline L. inopinata & 90 & -1.1 & 5.1 & 2.4 & -0.3 & 3.9 & 2.0 \\
\hline \multicolumn{8}{|l|}{ Sex } \\
\hline Female & 9 & 2.8 & 4.4 & 3.2 & 1.2 & 3.0 & 2.0 \\
\hline Male & 8 & 2.7 & 4.2 & 3.1 & 0.9 & 3.0 & 2.0 \\
\hline Difference $_{\text {male-female }}$ & 17 & 0.1 & 0.4 & 0.2 & 0.0 & 1.1 & 0.4 \\
\hline \multicolumn{8}{|l|}{ Valve size } \\
\hline $280-430 \mu \mathrm{m}$ & 5 & 2.1 & 3.5 & 2.8 & 1.4 & 3.0 & 2.0 \\
\hline $460-640 \mu \mathrm{m}$ & 7 & 2.8 & 3.5 & 3.1 & 1.2 & 3.0 & 1.9 \\
\hline Difference $_{\text {size }}$ & 12 & 0.0 & 1.0 & 0.4 & 0.0 & 0.5 & 0.2 \\
\hline \multicolumn{8}{|l|}{ Morphotype } \\
\hline Reticulated & 5 & 2.8 & 3.1 & 3.0 & 1.1 & 3.0 & 2.0 \\
\hline Smooth & 4 & 3.0 & 5.1 & 3.6 & 1.4 & 3.5 & 2.4 \\
\hline Difference $_{\text {reticulated-smooth }}$ & 11 & 0.0 & 1.9 & 0.50 & 0.3 & 0.9 & 0.6 \\
\hline Limnocythere sp. A & 40 & 0.9 & 5.1 & 3.5 & 1.7 & 3.5 & 2.6 \\
\hline \multicolumn{8}{|l|}{ Sex } \\
\hline Female & 1 & 4.16 & 4.16 & 4.16 & 3.47 & 3.47 & 3.47 \\
\hline Male & 1 & 4.14 & 4.14 & 4.14 & 3.53 & 3.53 & 3.53 \\
\hline Difference $_{\text {male-female }}$ & 2 & 0.02 & 0.02 & 0.02 & 0.06 & 0.06 & 0.06 \\
\hline Candona sp. & 10 & 2.2 & 4.8 & 3.7 & -3.9 & -0.6 & -1.4 \\
\hline
\end{tabular}

sediments for which porewater and biomarkers indicate deposition under lower salinity conditions (Fig. 2; Randlett et al., 2017; Tomonaga et al., 2017), and lithology and TOC suggest a well-ventilated water column (Stockhecke et al., 2014a). The presence of Candona sp., an infaunal genus (Decrouy et al., 2012), appears to be controlled here by a lower concentration of total dissolved salts, alkalinity and higher dissolved oxygen concentrations in the bottom water, rather than changes in the ionic composition of the lake water.

Limnocythere sp. A is near-constantly present between ca. 81 and $12 \mathrm{ka}$ and generally dominates the assemblage. Based on its occurrence restricted to the Last Glacial period (Fig. 2), coinciding with high porewater salinity and alkalinity (Tomonaga et al., 2017) and generally higher values for biomarker salinity proxies (Randlett et al., 2017), Limnocythere sp. A had likely a high salinity and/or high alkalinity preference. Between 26 and $18 \mathrm{ka}$, Limnocythere sp. A reached its highest relative taxonomic abundance of $86 \%$ to $98 \%$ (Fig. 2). At the same time, Lake Van's lake level was at its lowest and the salinity concentrations at its highest (ca. $50-80 \mathrm{~g} \mathrm{~kg}^{-1}$; Tomonaga et al., 2017). At the
Pleistocene-Holocene transition, characterised by more humid conditions, an increasing lake level and lower salinity (Litt et al., 2014; Tomonaga et al., 2017), Limnocythere sp. A disappeared from the sedimentary record.

\subsubsection{Noding in Limnocytherinae species (morphological variation)}

For some species (e.g. Cyprideis species and Leucocytherella sinensis, Huang, 1982) noding is a phenotypic reaction to a decrease in salinity (Keyser and Aladin, 2004; Keyser, 2005; Frenzel et al., 2012; Fürstenberg et al., 2015; Meyer et al., 2016). However, whether nodes in Limnocytherinae species, especially $L$. inopinata, are morphological traits that are genetically controlled (genotypic; Yin et al., 1999; Fuhrmann, 2012) or environmentally influenced (phenotypic; Benson, 1969 ) is at present open to debate. As far as we know, the occurrence of noded $L$. inopinata within a geological record has not been directly compared in detail to other proxies of past water hydrochemistry, including parameters such as salinity and alkalinity. While the physiological process of noding has 

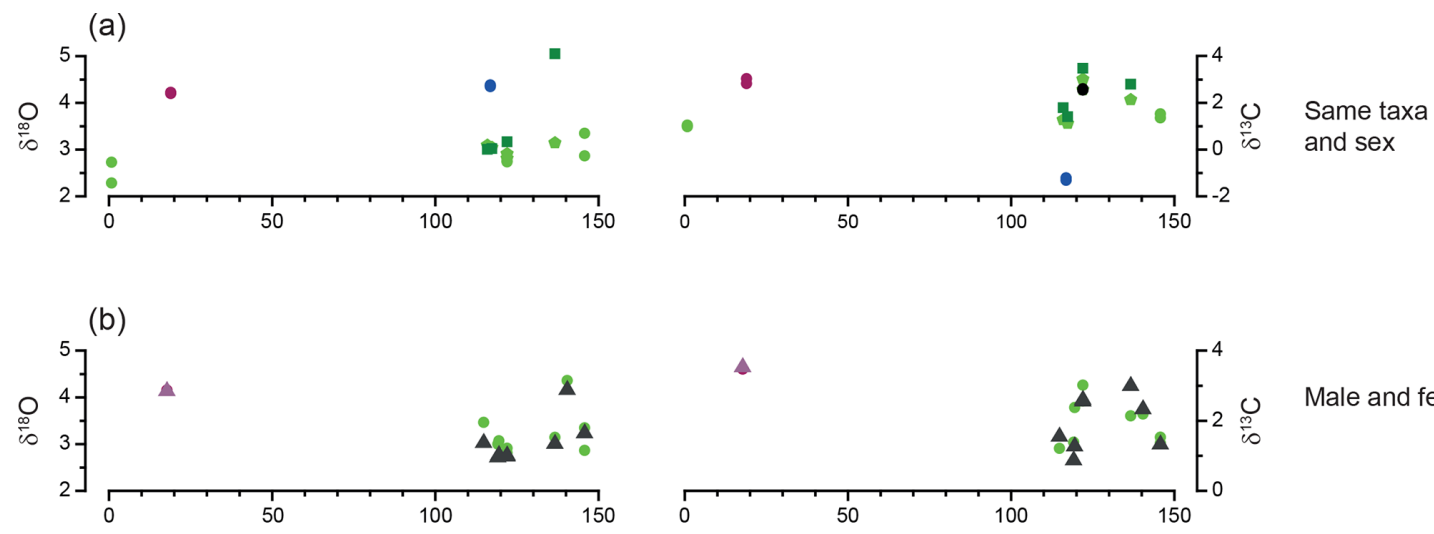

Male and female

(c)
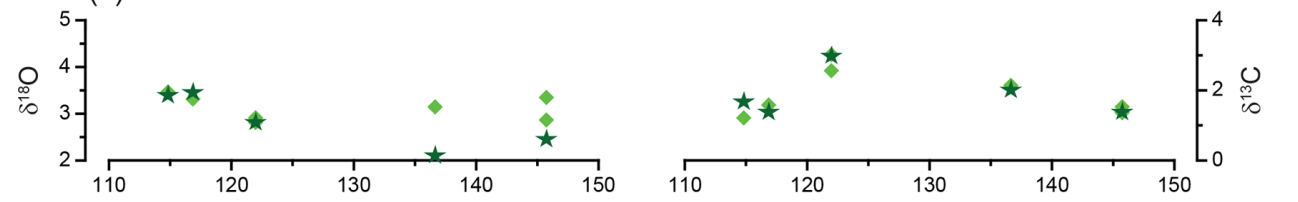

Different

valve size

(d)
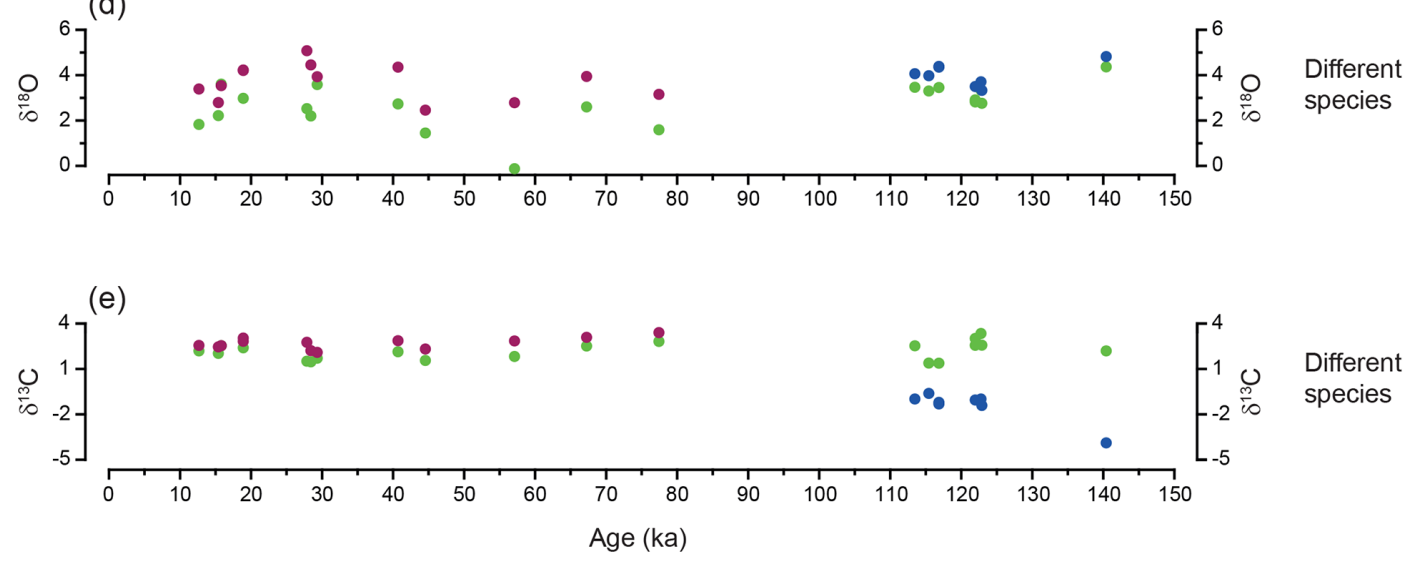

$$
\begin{aligned}
& \text { - L. inopinata }+\quad \Delta \text { L. inopinata smooth } \Delta \text { L. inopinata } \hat{\sigma} \quad \forall \text { L. inopinata 460-640 } \mu \mathrm{m} \\
& \text { - Limnocythere sp. A } \circ \quad \text { L. inopinata reticulated } \Delta \text { Limnocythere sp. A } \hat{\sigma} \quad \star \text { L. inopinata } 280-430 \mu \mathrm{m}
\end{aligned}
$$

Figure 5. Isotopic variability between ostracod measurements from the same stratigraphic horizon against age. (a) Variability between valves of the same taxa and sex. (b) Variability between $L$. inopinata and Limnocythere sp. A female and male valves. (c) Variability between $L$. inopinata of different valve size. (d) $\delta^{18} \mathrm{O}$ variability between $L$. inopinata and Limnocythere sp. A and L. inopinata and Candona sp. (e) ${ }^{13} \mathrm{C}$ variability between L. inopinata and Limnocythere sp. A and L. inopinata and Candona sp. Limnocythere sp. A and Candona sp. could not be compared, as they never occur in the same stratigraphic horizon.

been studied for $C$. torosa (Keyser, 2005), there are no such studies for Limnocytherinae species. In Lake Van, the highest concentration of noded L. inopinata and other Limnocytherinae species, in terms of the highest number of nodes per valve, and most pronounced nodes occurred during the Last Glacial period (Figs. 3, 4), strongly suggesting a relation with salinity (note that only samples with $\geq 20$ Limnocytherinae valves, excluding Limnocythere sp. A, were counted).
The number of noded individuals and the number of nodes per valve start to increase at the end of MIS 5 and reach maximum values during MIS 4 and 3. Concurrently, Lake Van data indicate generally increased lake water salinity, due to increased aridity and a decreasing lake level (Fig. 3; Litt et al., 2014; Stockhecke et al., 2014a; Pickarski et al., 2015; Tomonaga et al., 2017; Randlett et al., 2017). This observation is in disagreement with the interpretation of node for- 

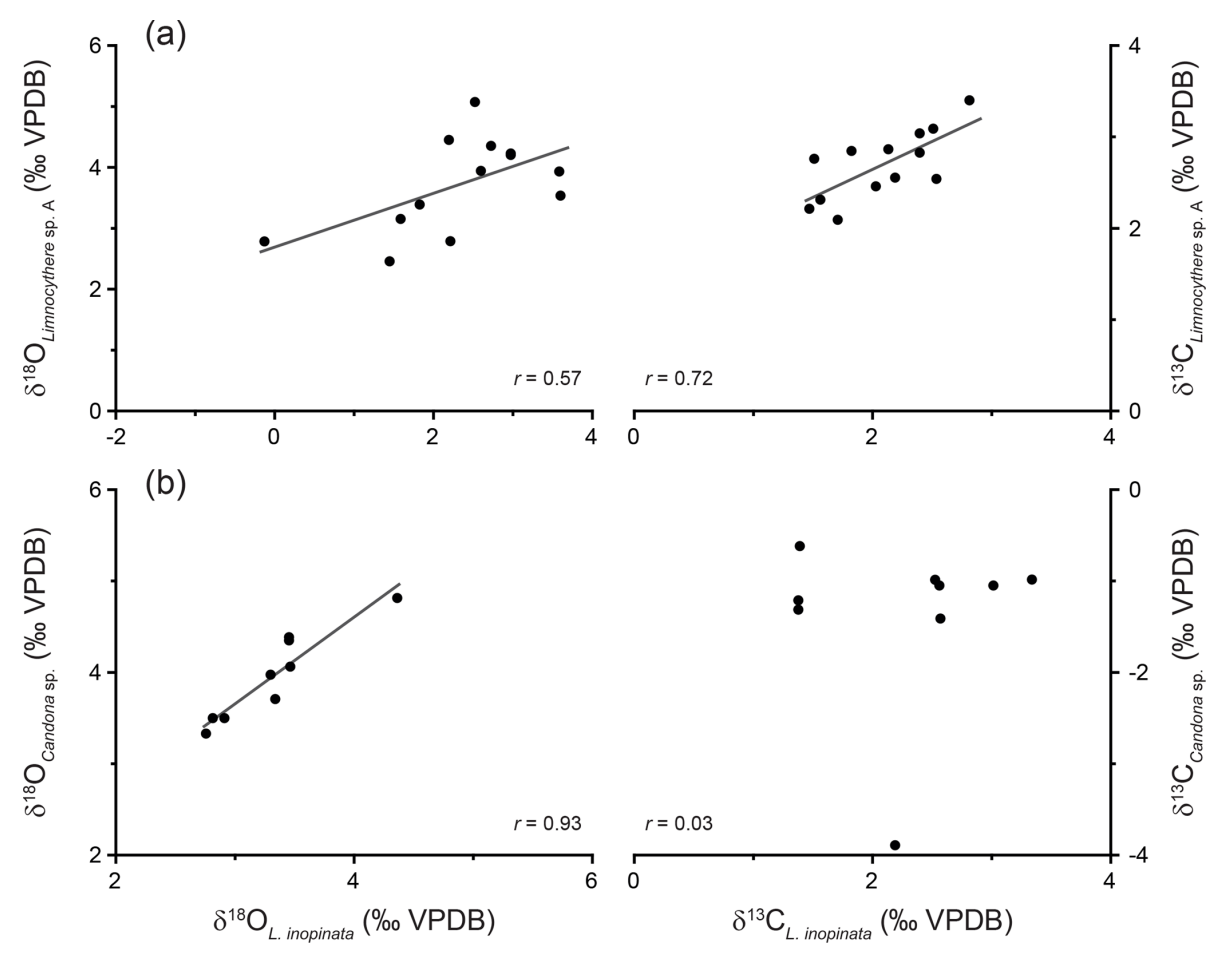

Figure 6. Isotopic composition of L. inopinata valves vs. Limnocythere sp. A (a) and Candona sp. (b).

mation as a genotypic trade suggested by Yin et al. (1999) referring to culture experiments exposing ostracods to variable aquaria water salinities. Based on the increase of noded individuals and the number of nodes under intensified aridity and increasing Lake Van salinity and alkalinity (Fig. 3), we propose that the node formation on Limnocytherinae species (incl. L. inopinata) is primarily a phenotypic phenomenon.

Further we suggest that nodes on $L$. inopinata represent a malfunction during or shortly after moulting, before the newly formed valves calcified, analogous to studies on $C$. torosa (Keyser and Aladin, 2004). During the hormoneinduced moulting process, the ostracod increases the volume of its bodily fluid by an intake of ambient water (Aladin and Potts, 1996; Keyser and Aladin, 2004). This leads to an inflation of the valve producing tissue, which under pressure that is too high may rupture during this process, leading to the formation of nodes during the subsequent biomineralisation (Keyser and Aladin, 2004; Keyser, 2005). According to Keyser (2005), the formation of nodes in C. torosa results from the lower osmotic pressure of the ambient water (low salinity) and the inability of the ostracod to regulate its internal osmotic pressure accordingly. A pressure that is higher than normal takes effect in the caverns between the inner and outer epidermal layers, when the ostracod presses its bodily fluid (haemolymph) into the valve. This is caused by the higher osmotic concentration within the haemolymph relative to the external aquatic medium. The higher pressure causes cell-to-cell connections between the inner and outer epidermal layer to tear, allowing the flexible valves to bulge out in these areas and form protrusions that are stabilised as nodes during the subsequent calcification. However, Limnocytherinae species (i.e. L. inopinata) are hyperosmotic regulators at salinities below $8 \mathrm{~g} \mathrm{~kg}^{-1}$ and isosmotic regulators between salinities of 8 and 14 to $20 \mathrm{~g} \mathrm{~kg}^{-1}$ (Aladin and Potts, 1996). Hence, we presume that the haemolymph of Limnocytherinae species will be hypo-osmotic relative to the lake water, and the mechanism of node formation is also related to the difficulty of achieving an osmotic balance during moulting.

Similar to the observation of van Harten (2000) for $C$. torosa, noded and unnoded valves of $L$. inopinata and other Limnocytherinae species typically co-occur, and while some stratigraphic horizons are free of noded valves, unnoded valves can be found throughout the profile. Keyser (2005) explains this by the ability of some individuals to better adjust to the environment. Not all individuals will have the same specific genetic predisposition (i.e. vulnerable cell-tocell connections between the inner and outer epidermal layer) triggered by less favourable environmental conditions (i.e. salinity or alkalinity). This may explain why there is no linear relationship between the relative abundance of noded valves and salinity (Fig. 3). However, it is evident that the occurrence of noded individuals and the number of nodes per valve are higher during periods of inferred high salinity from MIS 4 to 2 . Moreover, it is also noteworthy that the relative number of noded individuals increased again in the Holocene, 
but contrary to the Last Glacial period, the absolute size and number of nodes are smaller (Figs. 3f, 4). Keyser (2005) associated the size, shape, and extent of the protrusion (largest extent as spine) in $C$. torosa with the amount of pressure applied to the caverns between the epidermal layers, with larger nodes at higher pressure. In analogy to this, we interpret the higher number of nodes and the larger size of nodes for $L$. inopinata as an expression of enhanced environmental stress reflected in increased and more excessive malfunctions during moulting.

The $\mathrm{Ca}^{2+}$ deficiency in the water was suggested, next to salinity changes, as another driver of node formation in C. torosa (Keyser, 2005). Low $\mathrm{Ca}^{2+}$ concentrations within bodily fluid during moulting increase the risk of disrupting stabilising structural elements within the epidermal cavities by causing spasm-like reactions (Keyser, 2005; Frenzel et al., 2012). Modern Lake Van water is strongly Ca-depleted (0.105 to $0.087 \mathrm{mmol} \mathrm{L}^{-1}$; Reimer et al., 2009). We assume that lake water $\mathrm{Ca}^{2+}$ concentrations have not varied significantly within the last $150 \mathrm{kyr}$, as $\mathrm{Ca}^{2+}$ transported into the lake is quantitatively precipitated in the epilimnion as inorganic calcite and aragonite (McCormack et al., 2019a). The $\mathrm{Ca}^{2+}$ limitation in Lake Van may increase the likelihood of node formation in Limnocytherinae species but is apparently not the ultimate controlling mechanism.

The relation between noding and alkalinity is still unresolved (Van Harten, 2000; De Deckker and Lord, 2017). In Lake Van salinity and alkalinity of the porewater correlate exceptionally well, and both increased during the documented generally lower lake level of the Last Glacial (Tomonaga et al., 2017). Due to this correlation, we cannot evaluate the effect of either of these parameters on node formation independent of the other. Still, our results suggest that noding of $L$. inopinata and other Limnocytherinae species is controlled by ambient water salinity and perhaps alkalinity. Noding of Limnocytherinae species is therefore a valid indicator of relative palaeohydrological changes.

\subsection{Ostracod valve oxygen and carbon isotopy}

\subsubsection{Isotopic composition of ostracod valves and the "vital effect"}

Similar to other studies (e.g. Heaton et al., 1995; Li et al., 2007; Marco-Barba et al., 2012), we observe no systematic variation between sex, valve size, reticulation and the isotopic composition of ostracod valves of the same species in Lake Van (Fig. 5a-c; Table 1). The isotopic composition, however, varies systematically between different species from the same stratigraphic horizons (Fig. 5d, e). This observation may be related to different microhabitats or different vital effects. Ostracod calcite is typically enriched in ${ }^{18} \mathrm{O}$ (Xia et al., 1997; von Grafenstein et al., 1999) relative to inorganic calcite precipitated in isotopic equilibrium with the lake water (Kim and O'Neil, 1997) under the same geochemical conditions. While the exact controls of this vital offset remain ambiguous, its amplitude is species-specific (von Grafenstein et al., 1999) and perhaps related to the salinity and/or the ionic composition of the bottom water (Decrouy, 2011; Decrouy and Vennemann, 2013), water temperature, lake water $\mathrm{pH}$ conditions (Chivas et al., 2002) or the ambient water $\left[\mathrm{CO}_{3}^{2-}\right] /[\mathrm{DIC}]$ molar ratios (Devriendt et al., 2017).

In the same stratigraphic horizon, Limnocythere sp. A has, with one exception, constantly higher $\delta^{18} \mathrm{O}$ values relative to $L$. inopinata by a mean of $1.4 \%$ o $(n=13$; Fig. $5 \mathrm{~d})$. The positive correlation between the $\delta^{18} \mathrm{O}$ values of both species $\left(r=0.57\right.$, Fig. 6a) and the persistent ${ }^{18} \mathrm{O}$ enrichment in Limnocythere sp. A suggest a different vital offset from $L$. inopinata. Similarly, generally higher $\delta^{18} \mathrm{O}$ values of Candona sp., relative to $L$. inopinata (mean $0.6 \%$ or for $n=9$ ), indicate a different vital offset (Fig. 5d). The mean offset between Candoninae species and L. inopinata is lower than expected from studies in freshwater environments, in which the vital offset of Candoninae is ca. 2\%o to $3 \%$ and for $L$. inopinata ca. $0.8 \%$ (von Grafenstein, 1999; Keatings et al., 2002, Decrouy et al., 2011; Decrouy and Vennemann, 2013). The positive correlation between $\delta^{18} \mathrm{O}$ of L. inopinata and Candona sp. from the same stratigraphic horizon $(r=0.93$, Figs. 5d, 6b), however, not only supports a relatively constant vital offset between both taxa but also suggests that both respond to changes in the $\delta^{18} \mathrm{O}$ of the lake water.

Determining the vital offset for ostracod valve $\delta^{13} \mathrm{C}$ is more complex due to the species-specific microhabitat preferences of ostracods (von Grafenstein et al., 1999). Within the ostracods' microhabitat, the carbon isotope composition of the dissolved inorganic carbon $\left(\delta^{13} \mathrm{C}_{\mathrm{DIC}}\right)$ may vary significantly from that of the open water column (Decrouy et al., 2011). For most ostracod taxa (including Candoninae) the carbon isotopic composition presumably represents a value expected for equilibrium calcite formation (von Grafenstein et al., 1999; Keatings et al., 2002). The carbon isotope values of $L$. inopinata, however, are suggested to be $1 \%$ o to $3 \%$ o lower than what is expected for equilibrium precipitation, a feature that may be attributed to the biomineralisation pathway of the species (von Grafenstein et al., 1999; Decrouy et al., 2011). The $\delta^{13} \mathrm{C}$ values of Limnocythere sp. A are generally higher by ca. $0.6 \%$ relative to $L$. inopinata. The statistically relevant correlation between $\delta^{13} \mathrm{C}$ values of Limnocythere sp. A and L. inopinata $(r=0.72$; Figs. 5e, 6a) suggests a constant vital offset. Alternatively, both species may moult within different microhabitats. The second scenario explains the large offset between Candona sp. and $L$. inopinata $\delta^{13} \mathrm{C}$ values (Fig. 5e). While L. inopinata is a preferentially epifaunal species, the genus Candona sp. is considered to be infaunal (Decrouy et al., 2012b). The $\delta^{13} \mathrm{C}$ values of Candona sp. will in contrast to L. inopinata do not reflect the $\delta^{13} \mathrm{C}_{\text {DIC }}$ of the bottom water but instead that of the porewater. The oxidation of ${ }^{13} \mathrm{C}$-depleted organic matter shifts the $\delta^{13} \mathrm{C}_{\text {DIC }}$ of the porewater towards lower values 


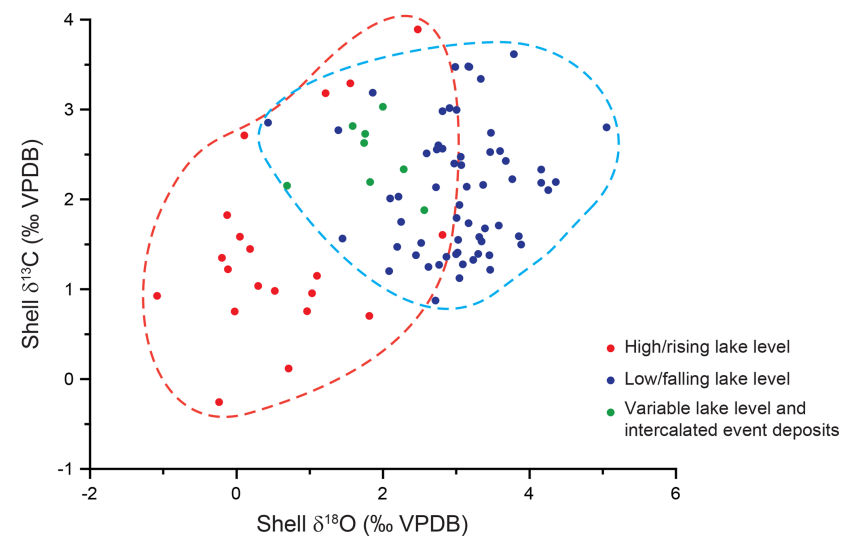

Figure 7. Ahlat Ridge L. inopinata $\delta^{18} \mathrm{O}$ vs. $\delta^{13} \mathrm{C}$ values, colour coded according to the lithology of their respective sampling horizon. Lithologies are colour coded according to their genetic interpretations related to lake level variability following Stockhecke et al. (2014a).

(von Grafenstein et al., 1999). The pronounced carbon isotope difference between both species implies a strong gradient between porewater and lake water $\delta^{13} \mathrm{C}_{\mathrm{DIC}}$ (Figs. 5e, 6b).

We cannot exclude the point that larger variations in the past water chemistry affected the magnitude of the biologically induced disequilibrium. However, the relatively constant offsets among the isotopic compositions of different species (Fig. 5d, e) implies only minor variations in the magnitude of the vital offsets. The offset between Candona sp. and $L$. inopinata $\delta^{13} \mathrm{C}$ values is an exception and is primarily a function of varying microhabitats. Variations in the isotopic composition of species-specific ostracod valves over glacialinterglacial timescales are larger than the potential amplitude of disequilibrium effects related to the biomineral secretion. Moreover, these patterns are synchronous with variations in other proxy records (Figs. 7, 8), indicating a sensitivity of the ostracod valve $\delta^{18} \mathrm{O}$ and $\delta^{13} \mathrm{C}$ records towards relative changes in Lake Van's palaeohydrology.

\subsubsection{Ostracod $\delta^{18} \mathrm{O}$ : palaeoenvironmental implications and comparison to inorganic carbonate isotope signatures}

The $\delta^{18} \mathrm{O}$ value of ostracod valves is not directly affected by salinity but rather by the isotopic composition and the temperature of the ambient water. In some cases ostracod valve $\delta^{18} \mathrm{O}$ is used to estimate relative changes in the lake volume (e.g. Lister, 1988; Gouramanis et al., 2010; Wrozyna et al., 2012; Marco-Barba et al., 2013), which also affect lake water salinity. Changes in the $\delta^{18} \mathrm{O}$ of the lake water $\left(\delta^{18} \mathrm{O}_{\text {lake }}\right)$ in large closed lakes are predominantly controlled by the precipitation / evaporation (P / E) ratio, with higher $\delta^{18} \mathrm{O}_{\text {lake }}$ values indicating lower $\mathrm{P} / \mathrm{E}$ ratios (decreasing lake level) due to the preferential loss of ${ }^{16} \mathrm{O}$ during evaporation (Leng and Marshall, 2004). A comparison of the isotopy of $L$. inopinata valves with the depositional lithostratigraphy indicates generally lower $\delta^{18} \mathrm{O}$ values for valves deposited in finely laminated sediments compared to such sedimented in banded or mottled deposits (Fig. 7). The generally lower $\delta^{18} \mathrm{O}$ values within laminated sediments deposited during high lake levels (Fig. 7) emphasise the sensitivity of ostracod valve chemistry in Lake Van to environmentally driven lake level fluctuations.

Despite its low resolution, $L$. inopinata $\delta^{18} \mathrm{O}$ data seem to reach lower values at the transition from the penultimate glacial period (MIS 6) to the Last Interglacial (MIS 5e; Fig. 8h). Ostracod valves are almost absent in the Ahlat Ridge sediments deposited during the early MIS 5e (124$133 \mathrm{ka}$; Fig. 2j), a period in which the lake level probably rose sufficiently to establish a short-lived outflow (Stockhecke et al., 2014a; Tomonaga et al., 2017; North et al., 2017). Apparently, this has led to a larger and/or more oxygen-depleted suboxic/anoxic water body compared to other highstand periods, preventing or hindering a colonisation of the profundal zone by ostracods. Subsequent periods representing lake level highstands (ca. 86-77 and 106-99 ka; Stockhecke et al., 2014; Tomonaga et al., 2017) document decreasing L. inopinata $\delta^{18} \mathrm{O}$ values (Fig. 8h) and thereby increasing $\mathrm{P} / \mathrm{E}$ ratios and decreasing salinity.

Within the sediments of MIS 3 and 4, high-amplitude fluctuations (>3\%o) in the Limnocythere sp. A and L. inopinata $\delta^{18} \mathrm{O}$ values likely indicate frequently changing $\mathrm{P} / \mathrm{E}$ ratios and a subsequent rising (interstadials) and falling (stadials) lake level. Limnocythere sp. A shows less variable, ${ }^{18} \mathrm{O}$-enriched values $(4 \%-5 \%$ o) between ca. 33 and $17 \mathrm{ka}$ (Fig. 8h, j). This supports relatively stable but arid conditions (Pickarski et al., 2015b; Kwiecien et al., 2014; Stockhecke et al., 2014a) and a low lake level (Cukur et al., 2014a, b; Tomonaga et al., 2014). Following the uniformly high values during MIS 2, Limnocythere sp. A $\delta^{18} \mathrm{O}$ values show a slight decrease (to ca. $2.8 \%$ ) at ca. $15 \mathrm{ka}$, while higher values (ca. 4.4\%o) are reached during the arid Younger Dryas. A significant rise in lake level at the onset of the Holocene (Landmann et al., 1996; Stockhecke et al., 2014a; Cukur et al., 2014a, b; Çağatay et al., 2014; Tomonaga et al., 2017), led to lower Holocene L. inopinata $\delta^{18} \mathrm{O}$ values (Fig. $8 \mathrm{~h}$ ).

The Lake Van bulk carbonate is composed of varying concentrations of the inorganic carbonate minerals aragonite, low-Mg calcite, and calcian dolomite and, volumetrically less important, biogenic carbonates (ostracods). The significantly different isotopic composition of each component results from their precipitation in isotopically distinct parent waters (McCormack et al., 2018, 2019a). McCormack et al. (2019a) have shown that both calcite and aragonite precipitate within isotopically contrasting surface water: calcite under close-to-freshwater conditions within river plumes and aragonite within evapoconcentrated lake water. Therefore, the bulk $\delta^{18} \mathrm{O}$ values, but also the isotopic composition of surface water precipitates calcite and aragonite $\left(\delta^{18} \mathrm{O}_{\mathrm{Ar}+\mathrm{Cc}}\right.$, $\delta^{13} \mathrm{C}_{\mathrm{Ar}+\mathrm{Cc}}$ ), represent isotopically mixed signals shifted towards the dominant polymorph. An estimation of the arag- 


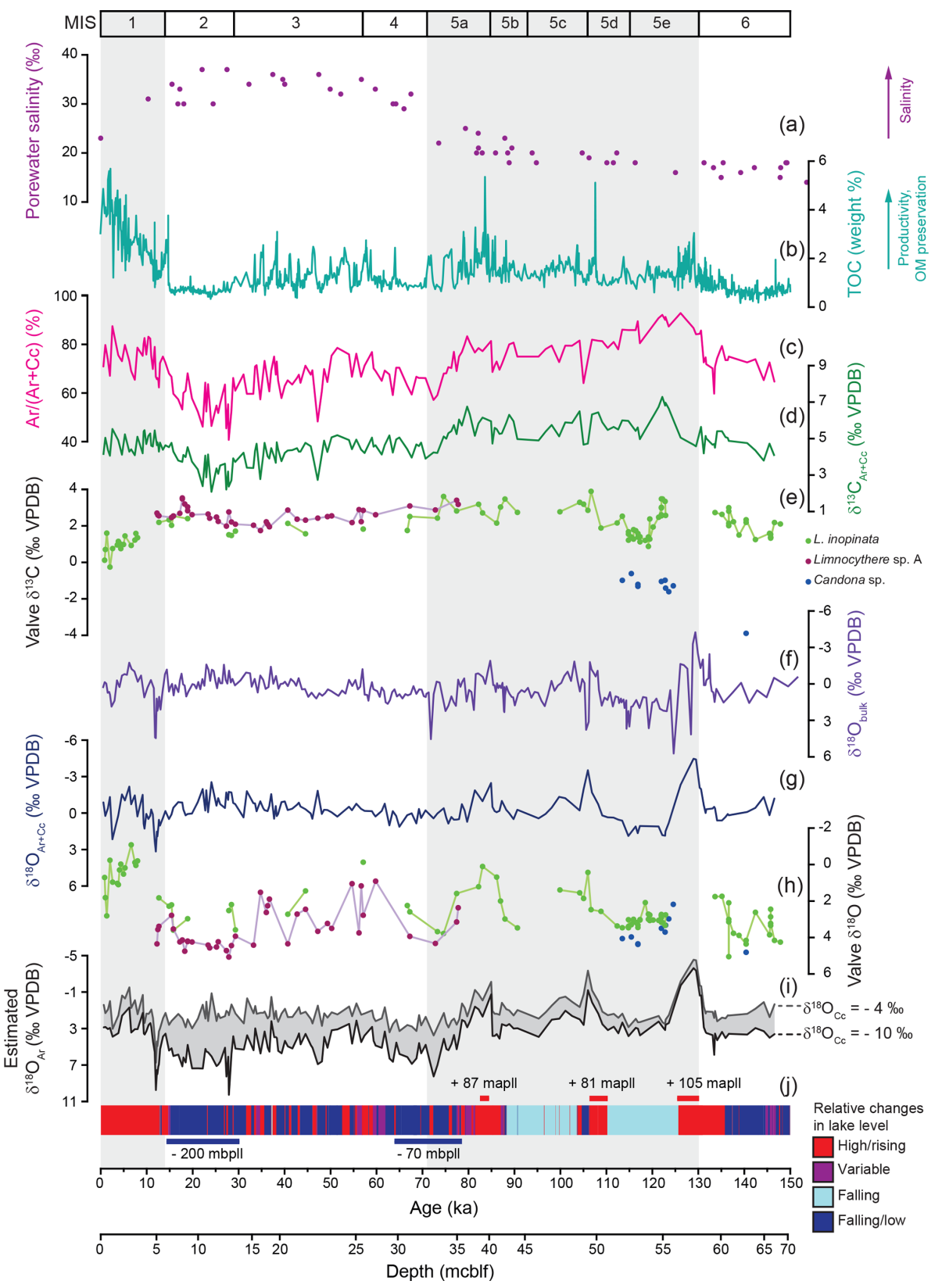

Figure 8. Ostracod isotopy compared with porewater salinity and inorganic carbonate isotopy and mineralogical composition. (a) Porewater salinity plotted against depth in metres' composite below lake floor (mcblf; Tomonaga et al., 2017). (b) Total organic carbon content (Stockhecke et al., 2014a). (c, d, g, i) Inorganic mineralogy and isotopy from McCormack at al. (2019). (c) Relative aragonite content of dolomite poor samples $(<15 \%$ dolomite) expressed by an aragonite/non-dolomite ratio $\mathrm{Ar} /(\mathrm{Ar}+\mathrm{Cc})$ in weight \% and (d, g) isotopic composition of dolomite poor samples $\left(\delta^{13} \mathrm{C}_{\mathrm{Ar}+\mathrm{Cc}}\right.$ and $\left.\delta^{18} \mathrm{O}_{\mathrm{Ar}+\mathrm{Cc}}\right)$. (f) Bulk carbonate oxygen isotope composition from Kwiecien et al. (2014). (i) Estimated $\delta^{18} \mathrm{O}_{\mathrm{Ar}}$ values for $\delta^{18} \mathrm{O}_{\mathrm{Cc}}$ values between $-4 \%$ and $-10 \%$. (j) Lithology-based relative lake level changes (simplified according to Stockhecke et al., 2014a) and major lake level variations (Stockhecke et al., 2014a; Tomonaga et al., 2017) in metres above/below present lake level (mapll/mbpll). (e, h) Valve $\delta^{18} \mathrm{O}$ values and $\delta^{13} \mathrm{C}$ values.

onite $\delta^{18} \mathrm{O}$ value $\left(\delta^{18} \mathrm{O}_{\mathrm{Ar}}\right)$ (assuming a range for the $\delta^{18} \mathrm{O}$ of calcite between $-4 \%$ and $-10 \%$ and a constant surface water temperature at the time of calcite precipitation at $10{ }^{\circ} \mathrm{C}$ ) represents the closest approximation for changes in Lake Van's surface water isotopic composition over glacial- interglacial timescales (McCormack et al., 2019a; Fig. 8i). The estimates of $\delta^{18} \mathrm{O}_{\mathrm{Ar}}$ values may be compromised by the uncertainty in the relative concentrations of aragonite and calcite and the adequacy of our assumptions. Nevertheless, the estimated $\delta^{18} \mathrm{O}_{\mathrm{Ar}}$ record shares more similarities with 
the $\delta^{18} \mathrm{O}$ pattern of ostracod valves than with the bulk $\delta^{18} \mathrm{O}$ record (Fig. 8). While the bulk $\delta^{18} \mathrm{O}$ record shows no systematic variations, both the estimated $\delta^{18} \mathrm{O}_{\mathrm{Ar}}$ and the $\delta^{18} \mathrm{O}_{\mathrm{Ar}+\mathrm{Cc}}$ records document decreasing values coinciding with the lake level highstands at ca. 106-99 and 86-77 ka, synchronous with the ostracod $\delta^{18} \mathrm{O}$ data. The shift towards lower $\delta^{18} \mathrm{O}_{\text {lake }}$ values from the late glacial into the Holocene, however, is evidenced by the estimated $\delta^{18} \mathrm{O}_{\mathrm{Ar}}$ and ostracod $\delta^{18} \mathrm{O}$ records but not in the $\delta^{18} \mathrm{O}_{\mathrm{Ar}+\mathrm{Cc}}$ or bulk record (Fig. $8 \mathrm{f}-\mathrm{i}$ ). The ostracod $\delta^{18} \mathrm{O}$ record shows a higher sensitivity to relative lake level changes than the inorganic isotope records in Lake Van. In conclusion, in lakes with a mixed inorganic carbonate composition, ostracod $\delta^{18} \mathrm{O}$ signatures may be a more accurate recorder of palaeohydrological changes than the $\delta^{18} \mathrm{O}$ values of inorganic carbonate.

\subsubsection{Ostracod $\delta^{13} \mathrm{C}$ : palaeoenvironmental implications and comparison to inorganic carbonate isotope signatures}

The species-specific $\delta^{13} \mathrm{C}$ variability is much lower than the respective $\delta^{18} \mathrm{O}$ variability (Fig. 8e, h). This pattern is particularly well pronounced within the Last Glacial period, when the amplitude of $\delta^{13} \mathrm{C}$ change is low for both $L$. inopinata and Limnocythere sp. A, while the amplitude of $\delta^{18} \mathrm{O}$ change is large. The lower variability in ostracod $\delta^{13} \mathrm{C}$ is probably related to the large dissolved inorganic carbon (DIC) pool of Lake Van (ca. $100 \mathrm{mmol} \mathrm{kg}^{-1}$, Reimer et al., 2009). In general, the $\delta^{13} \mathrm{C}$ of large DIC pools is less variable, with changes in the lakes hydrology compared to that of $\delta^{18} \mathrm{O}_{\text {lake }}$ ( $\mathrm{Li}$ and $\mathrm{Ku}, 1997)$. Importantly, the $\delta^{13} \mathrm{C}$ values of the infaunal Candona sp. valves do not reflect bottom water $\delta^{13} \mathrm{C}_{\text {DIC }}$ but the $\delta^{13} \mathrm{C}_{\mathrm{DIC}}$ of the porewater of the uppermost sediment column.

In contrast to the ostracod taxonomy, morphological variability, and valve $\delta^{18} \mathrm{O}$, the ostracod $\delta^{13} \mathrm{C}$ appears to be a less sensitive recorder of lake volume (salinity) or other hydrological changes in Lake Van. Still, markedly lower $\delta^{13} \mathrm{C}$ values of the epifaunal $L$. inopinata during two periods, the Holocene and the late MIS 5e (ca. 120 to $115 \mathrm{ka}$ ), document lower $\delta^{13} \mathrm{C}_{\text {DIC }}$ of the bottom water. Interestingly, for both periods, other proxy records (TOC, lithology and ostracod $\delta^{18} \mathrm{O}$; Fig. 8b, h, j) show contrasting signals. One interpretation of this feature is that the shift towards lower $\delta^{13} \mathrm{C}$ values was possibly triggered by different processes for each period. The decrease in L. inopinata $\delta^{13} \mathrm{C}$ values at the PleistoceneHolocene transition is here tentatively explained by the significant rise in the lake level (ca. $200 \mathrm{~m}$ ) and more humid conditions. This may have resulted in a dilution of the lake water by the influx of ${ }^{13} \mathrm{C}$-depleted freshwater. However, two previous lake level highstands at ca. 106-99 and 86-77 ka documenting decreasing $L$. inopinata $\delta^{18} \mathrm{O}$ values similar to the Holocene are not associated with decreasing $\delta^{13} \mathrm{C}$ values (Fig. 8e, h, j). Further, the low $\delta^{13} \mathrm{C}$ values in $L$. inopinata valves that calcified within the well-ventilated bottom water during the late MIS 5e (Stockhecke et al., 2014a) cannot be interpreted by increasing ${ }^{13} \mathrm{C}$-depleted runoff due to the very different depositional setting. Another potential explanation for lower ostracod valve $\delta^{13} \mathrm{C}$ values may be varying degrees of bottom water DIC exchange with upward diffusing ${ }^{13} \mathrm{C}$ depleted porewater at the lake floor. The lack of correlation between ostracod ${ }^{13} \mathrm{C}$ values and other proxy records and the differences in the depositional setting between both periods with lower $L$. inopinata $\delta^{13} \mathrm{C}$ values does not allow for a conclusive interpretation of our data.

While any palaeoenvironmental interpretation based on changes in ostracod $\delta^{13} \mathrm{C}$ remains at this point speculative, the shift towards lower values within Holocene sediments likely documents changes in the lake's bottom water DIC composition. An opposite trend towards higher values is clearly visible in the inorganic $\delta^{13} \mathrm{C}_{\mathrm{Ar}+\mathrm{Cc}}$ record (Fig. 8d, e). The complementary evolution in Holocene inorganic vs. os$\operatorname{tracod} \delta^{13} \mathrm{C}$ values may be related to a highly stratified water column. Given that $\delta^{13} \mathrm{C}_{\mathrm{Ar}+\mathrm{Cc}}$ is a mixture of ${ }^{13} \mathrm{C}$-enriched aragonite and comparably ${ }^{13} \mathrm{C}$-depleted calcite, the Holocene increase in aragonite content (Fig. 8c, McCormack et al., 2019a) may have masked a trend towards lower water column $\delta^{13} \mathrm{C}_{\text {DIC }}$.

\section{Conclusions}

Taking advantage of the legacy of the ICDP PALEOVAN project - the well-documented hydrological evolution of Lake Van - this study examined the applicability of ostracods as multi-proxy archives for relative changes of the past lake water chemistry, with an emphasis on salinity reconstructions. We focussed on the ostracod faunal assemblage, valve morphology (noding) of Limnocytherinae species (incl. Limnocythere inopinata) and the valve geochemistry $\left(\delta^{18} \mathrm{O}\right.$ and $\delta^{13} \mathrm{C}$ ) of three different ostracod taxa from ICDP cores covering the last $150 \mathrm{kyr}$. We conclude the following points:

1. The composition of the ostracod assemblage of Lake Van is primarily controlled by the salinity and/or alkalinity of the lake water. While Limnocythere sp. A is present only during high salinity and alkalinity intervals, Candona sp. valves are limited to periods of less saline lake water. Limnocythere inopinata, a cosmopoli$\tan$ species with high tolerance to changing water chemistry, is present throughout the record.

2. The presence and number of nodes (hollow protrusions) are compared here to independent palaeohydrological proxies. Our results indicate that node formation on valves of Limnocytherinae species is primarily a phenotypic response to higher salinity and/or alkalinity and as such represents a novel promising proxy in semiquantitative lacustrine palaeohydrology.

3. The $\delta^{18} \mathrm{O}$ records from ostracods in Lake Van are sensitive towards relative changes in the lake volume re- 
lated to varying precipitation / evaporation ratios. Ostracod valves generally have lower $\delta^{18} \mathrm{O}$ values when embedded in sediments deposited during lake level highstands and higher values when embedded in sediments deposited during a low lake level.

4. Ostracod $\delta^{13} \mathrm{C}$ values, while less sensitive to hydrological changes due to the large dissolved inorganic carbon pool of Lake Van, still reflect the microhabitat of the respective species.

5. The isotopic composition of ostracod valves, particularly their $\delta^{18} \mathrm{O}$ values, documents hydrological changes that are not recorded by the inorganic (bulk) isotope records due to their mineralogically mixed composition. The isotopic analyses of ostracod valves are therefore particularly useful for estimating changes in the isotopic composition of the water in lakes in which more than one inorganic carbonate phase accumulates in the bulk sediment.

Data availability. The data can be found under https://doi.org/10.17632/8bfshc85ww.2 (McCormack, 2019).

Author contributions. OK and JM designed the study. JM wrote the paper, made figures and tables and performed lab and data analysis work. FV, DA and JM were involved in species and morphotype identification. All authors discussed the results and helped in paper preparation. JM, OK, FV and AI edited the final draft.

Competing interests. The authors declare that they have no conflict of interest.

Acknowledgements. We acknowledge funding from the Deutsche Forschungsgemeinschaft (DFG). We are grateful to Sebastian Breitenbach, Matthias Born, and Rolf Neuser for instrumental assistance and appreciate the assistance of Julian Stromann and Annabel Wolf with the sample sieving. The paper benefited from the thorough, positive and constructive feedback from Neil Roberts, Anna Pint, and one anonymous referee and the professional handling by the associate editor S. Wajih A. Naqvi.

Financial support. This research was supported by the Deutsche Forschungsgemeinschaft (DFG) (grant no. KW90/2-1).

Review statement. This paper was edited by S. Wajih A. Naqvi and reviewed by Anna Pint, C. Neil Roberts, and one anonymous referee.

\section{References}

Aladin, N. V. and Potts, W. T. W.: Changes in the Aral Sea ecosystems during the period 1960-1990, Hydrobiologia, 237, 67-79, https://doi.org/10.1007/BF00016032, 1992.

Aladin, N. V. and Potts, W. T. W.: The osmoregulatory capacity of the Ostracoda, J. Comp. Physiol. B, 166, 215-222, https://doi.org/10.1007/BF00263985, 1996.

Anadón, P., De Deckker, P., and Julia, R.: The Pleistocene lake deposits of the NE Baza Basin (Spain): salinity variations and ostracod succession, Hydrobiologia, 143, 199-208, https://doi.org/10.1007/BF00026662, 1986.

Bahr, A., Lamy, F., Arz, H. W., Major, C., Kwiecien, O., and Wefer, G.: Abrupt changes of temperature and water chemistry in the late Pleistocene and early Holocene Black Sea, Geochem. Geophys. Geosyst., 9, 1-16, https://doi.org/10.1029/2007GC001683, 2008.

Baird, W.: Notes on British Entomostraca, The Zoologist - A Popular Miscellany of Natural History, 1, 193-197, 1843.

Barker, S., Knorr, G., Edwards, R. L., Parrenin, F., Putnam, A. E., Skinner, L. C., Wolff, E., and Ziegler, M.: 800,000 years of abrupt climate variability, Science, 334, 347-351, https://doi.org/10.1126/science.1203580, 2011.

Benson, R. H.: Ostracodes of the Rita Blanca lake deposits, Geol. Soc. Am. Mem., 113, 107-115, 1969.

Bernasconi, S. M., Müller, I. A., Bergmann, K. D., Breitenbach, S. F. M., Fernandez, A., Hodell, D. A., Meckler, A. N., Millan, I., and Ziegler, M.: Reducing uncertainties in carbonate clumped isotope analysis through consistent carbonate-based standardization, Geochem. Geophys. Geosyst., 19, 2895-2914, https://doi.org/10.1029/2017GC007385, 2018.

Boomer, I., Horne, D. J., and Slipper, I. J.: The use of ostracods in palaeoenvironmental studies, or what can you do with an ostracod shell?, Paleontol. Soc. Papers, 9, 153-180, https://doi.org/10.1017/S1089332600002199, 2003.

Bubikjan, S. A.: Ostracoda from Pliocene deposits of Armenia, Ostrakody iz Pliotsenovykh otlozheniy Armenii, Izvestiia Akademii Nauk Armyanskoy SSR, Seriya nauki o zemle 19, 3-11, 1966.

Bubikjan, S. A.: Recent Ostracoda from the bottom beds of the south-western part of Lake Sevan, Izvestia Akademii nauk Armanskoj SSR, Naukii o Zemlye 37, 10-24, 1984.

Çağatay, M. N., Öğretmen, N., Damcı, E., Stockhecke, M., Sancar, Ü., Eriş, K. K., and Özeren, S.: Lake level and climate records of the last $90 \mathrm{ka}$ from the Northern Basin of Lake Van, eastern Turkey, Quaternary Sci. Rev., 104, 97-116, https://doi.org/10.1016/j.quascirev.2014.09.027, 2014.

Carbonel, P., Colin, J. P., Danielopol, D. L., Löffler, H., and Neustrueva, I.: Paleoecology of limnic ostracodes: a review of some major topics, Palaeogeogr. Palaeocl., 62, 413-461, https://doi.org/10.1016/0031-0182(88)90066-1, 1988.

Chapman, M. A.: On Eucypris mytiloides (Brady), and three new species of Eucypris Vavra (Cypridae, Ostracoda) from Australia, Hydrobiologia, 27, 368-378, https://doi.org/10.1007/BF00042699, 1966.

Chivas, A. R., De Deckker, P., Wang, S. X., and Cali, J. A.: Oxygen-isotope systematics of the nektic ostracod Australocypris robusta, in: The Ostracoda: Applications in Quaternary Research, edited by: Holmes, J. A., and Chivas, A. R., American Geophysical Union, Washington, DC, 301-313, https://doi.org/10.1029/GM131, 2002. 
Cukur, D., Krastel, S., Schmincke, H. U., Sumita, M., Çağatay, M. N., Meydan, A. F., Damci, E., and Stockhecke, M.: Seismic stratigraphy of Lake Van, eastern Turkey, Quaternary Sci. Rev., 104, 63-84, https://doi.org/10.1016/j.quascirev.2014.07.016, 2014a.

Cukur, D., Krastel, S., Schmincke, H. U., Sumita, M., Tomonaga, Y., and Çağatay, M. N.: Water level changes in Lake Van, Turkey, during the past ca. $600 \mathrm{ka}$ : climatic, volcanic and tectonic controls J. Paleolimnol., 52, 201-214, https://doi.org/10.1007/s10933-014-9788-0, 2014b.

Dana, G. L. and Lenz, P. H.: Effects of increasing salinity on an Artemia population from Mono Lake, California, Oecologia, 68, 428-436, https://doi.org/10.1007/BF01036751, 1986.

Danielopol, D. L., Cabral, M. C., Lord, A., Carbonel, P., Gross, M., Stoica, M., Humphreys, W. F., Namiotko, T., Tóth, E., Külköylüoğlu, O., Piller, W. E., and Nunes, T.: Sieve-type pore canals in the Timiriaseviinae - A contribution to the comparative morphology and the systematics of the Limnocytheridae (Ostracoda, Crustacea), Zootaxa, 4495, 1-64, https://doi.org/10.11646/zootaxa.4495.1.1., 2018.

De Deckker, P. and Forester, R. M.: The Use of Ostracods to Reconstruct Palaeoenvironmental Records, in: Ostracoda in the Earth Sciences, edited by: De Deckker, P., Colin, J. P., and Peypouquet, J. P., Elsevier, Amsterdam, 175-199, 1988.

De Deckker, P.: Ostracods of athalassic saline lakes, Hydrobiologica, 81, 131-144, https://doi.org/10.1007/978-94-009-86657_10, 1981.

De Deckker, P. and Lord, A.: Cyprideis torosa: a model organism for the Ostracoda?, J. Micropalaeontol., 36, 3-6, https://doi.org/10.1144/jmpaleo2016-100, 2017.

De Deckker, P., Chivas, A. R., and Shelley, J. M. G.: Uptake of $\mathrm{Mg}$ and $\mathrm{Sr}$ in the euryhaline ostracod Cyprideis determined from in vitro experiments, Palaeogeogr. Palaeocl., 148, 105-116, https://doi.org/10.1016/S0031-0182(98)00178-3, 1999.

Decrouy, L.: Biological and environmental controls on isotopes in ostracod shells, in: Ostracoda as proxies for quaternary climate change, edited by: Horne, D., Holmes, J., RodriguezLazaro, J., and Viehberg, F., Elsevier, Oxford, 165-181, https://doi.org/10.1016/B978-0-444-53636-5.00010-X, 2012.

Decrouy, L. and Vennemann, T. W.: Potential influence of the chemical composition of water on the stable oxygen isotope composition of continental ostracods, J. Paleolimnol., 50, 577-582, https://doi.org/10.1007/s10933-013-9719-5, 2013.

Decrouy, L., Vennemann, T. W., and Ariztegui, D.: Controls on ostracod valve geochemistry: Part 2. Carbon and oxygen isotope compositions, Geochim. Cosmochim. Ac., 75, 7380-7399, https://doi.org/10.1016/j.gca.2011.09.008, 2011.

Decrouy, L., Vennemann, T. W., and Ariztegui, D.: Sediment penetration depths of epi-and infaunal ostracods from Lake Geneva (Switzerland), Hydrobiologia, 688, 5-23, https://doi.org/10.1007/s10750-010-0561-8, 2012.

Devriendt, L. S., McGregor, H. V., and Chivas, A. R.: Ostracod calcite records the ${ }^{18} \mathrm{O} /{ }^{16} \mathrm{O}$ ratio of the bicarbonate and carbonate ions in water, Geochim. Cosmochim. Ac., 214, 30-50, https://doi.org/10.1016/j.gca.2017.06.044. 2017.

Digerfeldt, G., Olsson, S., and Sandgren, P.: Reconstruction of lake-level changes in lake Xinias, central Greece, during the last 40000 years, Palaeogeogr. Palaeocl., 158, 65-82, https://doi.org/10.1016/S0031-0182(00)00029-8. 2000.
Dor, Y. B., Armon, M., Ahlborn, M., Morin, E., Erel, Y., Brauer, A., Schwab, M. J., Tjallingii, R., and Enzel, Y.: Changing flood frequencies under opposing late Pleistocene eastern Mediterranean climates, Sci. Rep., 8, 1-10, https://doi.org/10.1038/s41598-01825969-6, 2018.

Edwards, S., McKirdy, D. M., Bone, Y., Gell, P. A., and Gostin, V. A.: Diatoms and ostracods as mid-Holocene palaeoenvironmental indicators, North Stromatolite Lake, Coorong National Park, South Australia, Aust. J. Earth Sci., 53, 651-663, https://doi.org/10.1080/08120090600686801. 2006.

Engstrom, D. R. and Nelson, S. R.: Paleosalinity from trace metals in fossil ostracodes compared with observational records at Devils Lake, North Dakota, USA, Palaeogeogr. Palaeocl., 83, 295312, https://doi.org/10.1016/0031-0182(91)90057-X, 1991.

Forester, R. M.: Relationship of two lacustrine ostracode species to solute composition and salinity: implications for paleohydrochemistry, Geology, 11, 435-438, https://doi.org/10.1130/00917613(1983)11<435:ROTLOS> 2.0.CO;2, 1983.

Forester, R. M.: Determination of the dissolved anion composition of ancient lakes from fossil ostracodes, Geology, 14, 796-799, https://doi.org/10.1130/00917613(1986)14<796:DOTDAC>2.0.CO;2, 1986.

Forester, R. M.: Pliocene-climate history of the western United States derived from lacustrine ostracodes, Quaternary Sci. Rev., 10, 133-146, https://doi.org/10.1016/0277-3791(91)90014-L. 1991.

Forester, R. M. and Brouwers, E. M.: Hydrochemical parameters governing the occurrence of estuarine and marginal estuarine ostracodes: an example from south-central Alaska, J. Paleontol., 59, 344-369, 1985.

Frenzel, P., Schulze, I., and Pint, A.: Noding of Cyprideis torosa valves (Ostracoda) - a proxy for salinity? New data from field observations and a long-term microcosm experiment, Int. Rev. Hydrobiol., 97, 314-329, https://doi.org/10.1002/iroh.201211494, 2012.

Frogley, M. R., Griffiths, H. I., and Heaton, T. H.: Historical biogeography and Late Quaternary environmental change of Lake Pamvotis, Ioannina (north-western Greece): evidence from ostracods, J. Biogeogr., 28, 745-756, https://doi.org/10.1046/j.13652699.2001.00582.x. 2001.

Fuhrmann R.: Atlas quartärer und rezenter Ostrakoden Mitteldeutschlands. Naturkundliches Museum Mauritianum, Altenburg, 2012.

Fürstenberg, S., Frenzel, P., Peng, P., Henkel, K., and Wrozyna, C.: Phenotypical variation in Leucocytherella sinensis Huang, 1982 (Ostracoda): a new proxy for palaeosalinity in Tibetan lakes, Hydrobiologia, 751, 55-72, 2015.

Gouramanis, C. and De Deckker, P.: Alkalinity control on the partition coefficients in lacustrine ostracodes from Australia, Geology, 38, 359-362, https://doi.org/10.1130/G30235.1, 2010.

Gouramanis, C., Wilkins, D., and De Deckker, P.: 6000 years of environmental changes recorded in Blue Lake, South Australia, based on ostracod ecology and valve chemistry, Palaeogeogr. Palaeocl., 297, 223-237, https://doi.org/10.1016/j.palaeo.2010.08.005, 2010.

Hammarlund, D., Aravena, R., Barnekow, L., Buchardt, B., and Possnert, G.: Multi-component carbon isotope evidence of early Holocene environmental change and carbon-flow pathways from 
a hard-water lake in northern Sweden, J. Paleolimnol., 18, 219233, https://doi.org/10.1023/A:1007953614927, 1997.

Heaton, T. H. E., Holmes, J. A., and Bridgwater, N. D.: Carbon and oxygen isotope variations among lacustrine ostracods: implications for palaeoclimatic studies, The Holocene, 5, 428-434, https://doi.org/10.1177/095968369500500405, 1995.

Holmes, J. A.: Trace-element and stable-isotope geochemistry of non-marine ostracod shells in Quaternary palaeoenvironmental reconstruction, J. Paleolimnol., 15, 223-235, https://doi.org/10.1007/BF00213042, 1996.

Holmes, J. A. and De Deckker, P.: The chemical composition of ostracod shells: applications in Quaternary palaeoclimatology, in: Ostracoda as proxies for quaternary climate change, edited by: Horne, D., Holmes, J., Rodriguez-Lazaro, J., and Viehberg, F., Elsevier, Oxford, 131-143, https://doi.org/10.1016/B978-0-44453636-5.00008-1, 2012.

Holmes, J. A., Allen, M. J., Street-Perrott, F. A., Ivanovich, M., Perrott, R. A., and Waller, M. P.: Late Holocene palaeolimnology of Bal Lake, northern Nigeria, a multidisciplinary study, Palaeogeogr. Palaeocl., 148, 169-185, https://doi.org/10.1016/S00310182(98)00182-5, 1999.

Holmes, J., Sayer, C. D., Liptrot, E., and Hoare, D. J.: Complex controls on ostracod palaeoecology in a shallow coastal brackishwater lake: implications for palaeosalinity reconstruction, Freshwater Biology, 55, 2484-2498, https://doi.org/10.1111/j.13652427.2010.02478.x, 2010.

Horne, D. J., Holmes, J. A., Rodriguez-Lazaro, J., and Viehberg, F. A.: Ostracoda as proxies for Quaternary climate change: overview and future prospects, in: Ostracoda as proxies for quaternary climate change, edited by: Horne, D., Holmes, J., Rodriguez-Lazaro, J., and Viehberg, F., Elsevier, Oxford, 305-315, https://doi.org/10.1016/B978-0-444-53636-5.00018-4, 2012.

Huang, B., Yang H., and You, K.,: Pliocene and Quaternary Ostracoda from southern and southwestern Xizang, in: Integrated Survey of Tibetan Plateau of Chinese Academy of Sciences, Palaeobiology of Xizang, 4, 326-348, 1982.

Jones, M. D., Abu-Jaber, N., AlShdaifat, A., Baird, D., Cook, B. I., Cuthbert, M. O., Dean, J. R., Djamali, M., Eastwood, W., Fleitmann, D., Haywood, A., Kwiecien, O., Larsen, J., Maher, L. A., Metcalfe, S. E., Parker, A., Petrie, C. A., Primmer, N., Richter, T., Roberts, N., Roe, J., Tindall, J. C., Ünal-Imer, E., and Weeks, L.: 20,000 years of societal vulnerability and adaptation to climate change in southwest Asia, WIREs Water, 6, 1-31, https://doi.org/10.1002/wat2.1330, 2018.

Jones, T. R.: Description of the Entomostraca of the Pleistocene Beds of Newbury, Copford, Clacton, and Grays, The Annals and Magazine of Natural History Series, 2, 25-28, 1850.

Karanovic, I.: Recent Freshwater Ostracods of the World, SpringerVerlag, Berlin, 2012.

Keatings, K. W., Heaton, T. H. E., and Holmes, J. A.: Carbon and oxygen isotope fractionation in non-marine ostracods: results from a "natural culture" environment, Geochim. Cosmochim. Ac., 66, 1701-1711, https://doi.org/10.1016/S00167037(01)00894-8, 2002.

Keatings, K., Holmes, J., Flower, R., Horne, D., Whittaker, J. E., and Abu-Zied, R. H.: Ostracods and the Holocene palaeolimnology of Lake Qarun, with special reference to past humanenvironment interactions in the Faiyum (Egypt), Hydrobiolo- gia, 654, 155-176, https://doi.org/10.1007/s10750-010-0379-4, 2010.

Kelts, K. and Talbot, M.: Lacustrine carbonates as geochemical archives of environmental change and biotic/abiotic interactions, in: Large Lakes: Ecological Structure and Function, edited by: Tilzer, M. M. and Serruya, C., Science Technical Publications, Madison, 290-317, 1990.

Kempe, S., Kazmierczak, J., Landmann, G., Konuk, T., Reimer, A., and Lipp, A.: Largest known microbialites discovered in Lake Van, Turkey, Nature, 349, 605-608, https://doi.org/10.1038/349605a0, 1991.

Keyser, D.: Histological peculiarities of the noding process in Cyprideis torosa (Jones)(Crustacea, Ostracoda), Hydrobiologia, 538, 95-106, https://doi.org/10.1007/s10750-004-4940-x, 2005.

Keyser, D. and Aladin, N.: Noding in Cyprideis torosa and its causes, Studia Quaternaria, 21, 19-24, 2004.

Kilenyi, T. I.: Transient and balanced genetic polymorphism as an explanation of variable noding in the ostracode Cyprideis torosa, Micropaleontology, 18, 47-63, https://doi.org/10.2307/1484978, 1972.

Kim, S. T. and O'Neil, J. R.: Equilibrium and nonequilibrium oxygen isotope effects in synthetic carbonates, Geochim. Cosmochim. Ac., 61, 3461-3475, https://doi.org/10.1016/S00167037(97)00169-5, 1997.

Külköylüoğlu, O., Sari, N., and Akdemir, D.: Distribution and ecological requirements of ostracods (Crustacea) at high altitudinal ranges in Northeastern Van (Turkey), Ann. Limnol.-Int. J. Lim., 48, 39-51, https://doi.org/10.1051/limn/2011060, 2012.

Kwiecien, O., Stockhecke, M., Pickarski, N., Heumann, G., Litt, T., Sturm, M., Anselmetti, F., Kipfer, R., and Haug, G. H.: Dynamics of the last four glacial terminations recorded in Lake Van, Turkey, Quaternary Sci. Rev., 104, 42-52, https://doi.org/10.1016/j.quascirev.2014.07.001, 2014.

Landmann, G., Reimer, A., and Kempe, S.: Climatically induced lake level changes at Lake Van, Turkey, during the Pleistocene/Holocene transition, Glob. Biogeochem. Cy., 10, 797808, https://doi.org/10.1029/96GB02347, 1996.

Leng, M. J. and Marshall, J. D.: Palaeoclimate interpretation of stable isotope data from lake sediment archives, Quaternary Sci. Rev., 23, 811-831, https://doi.org/10.1016/j.quascirev.2003.06.012, 2004.

Li, H. C. and Ku, T. L.: $\delta^{13} \mathrm{C}-\delta^{18} \mathrm{C}$ covariance as a paleohydrological indicator for closed-basin lakes, Palaeogeogr. Palaeocl., 133, 69-80, https://doi.org/10.1016/S0031-0182(96)00153-8, 1997.

Li, X., Liu, W., Zhang, L., and Sun, Z.: Distribution of recent ostracod species in the Lake Qinghai area in northwestern China and its ecological significance, Ecol. Indic., 10, 880-890, https://doi.org/10.1016/j.ecolind.2010.01.012, 2010.

Li, X., Liu, W., Zhang, P., An, Z., and Zhang, L.: Species, valve size, and pretreatment effects on $\delta^{18} \mathrm{O}$ and $\delta^{13} \mathrm{C}$ values of ostracod valves from Lake Qinghai, Qinghai-Tibet Plateau, Chem. Geol., 246, 124-134, https://doi.org/10.1016/j.chemgeo.2007.09.007, 2007.

Lister, G. S.: Stable isotopes from lacustrine Ostracoda as tracers for continental palaeoenvironments, in: Ostracoda in the Earth Sciences, edited by: De Deckker, P., Colin, J. P., and Peypouquet, J. P., Elsevier, Amsterdam, 201-218, 1988. 
Litt, T. and Anselmetti, F. S.: Lake Van deep drilling project PALEOVAN, Quaternary Sci. Rev., 104, 1-7, https://doi.org/10.5194/sd-14-18-2012, 2014.

Litt, T., Anselmetti, F. S., Baumgarten, H., Beer, J., Cagatay, N., Cukur, D., Damci, E., Glombitza, C., Haug, G., Heumann, G., Kallmeyer, H., Kipfer, R., Krastel, S., Kwiecien, O., Meydan, A. F., Orcen, S., Pickarski, N., Randlett, M.-E., Schmincke, H.-U., Schubert, C. J., Sturm, M., Sumita, M., Stockhecke, M., Tomonaga, Y., Vigliotti, L., Wonik, T., and the PALEOVAN Scientific Team: 500,000 Years of Environmental History in Eastern Anatolia: The PALEOVAN Drilling Project, Sci. Dril., 14, 18-29, https://doi.org/10.2204/iodp.sd.14.02.2012, 2012.

Litt, T., Krastel, S., Sturm, M., Kipfer, R., Örcen, S., Heumann, G., Franz, S. O., Ülgen, U. B., and Niessen, F.: "PALEOVAN", International Continental Scientific Drilling Program (ICDP): site survey results and perspectives, Quaternary Sci. Rev., 28, 15551567, https://doi.org/10.1016/j.quascirev.2009.03.002, 2009.

Litt, T., Pickarski, N., Heumann, G., Stockhecke, M., and Tzedakis, P. C.: A 600,000 year long continental pollen record from Lake Van, eastern Anatolia (Turkey), Quaternary Sci. Rev., 104, 3041, https://doi.org/10.1016/j.quascirev.2014.03.017, 2014.

Marco-Barba, J., Ito, E., Carbonell, E., and Mesquita-Joanes, F.: Empirical calibration of shell chemistry of Cyprideis torosa (Jones, 1850)(Crustacea: Ostracoda), Geochim. Cosmochim. Ac., 93, 143-163, https://doi.org/10.1016/j.gca.2012.06.019. 2012.

Marco-Barba, J., Mesquita-Joanes, F., and Miracle, M. R.: Ostracod palaeolimnological analysis reveals drastic historical changes in salinity, eutrophication and biodiversity loss in a coastal Mediterranean lake, The Holocene, 23, 556-567, https://doi.org/10.1177/0959683612466752, 2013.

Martens, K.: Effects of temperature and salinity on postembryonic growth in Mytilocypris henricae (Chapman)(Crustacea, Ostracoda), J. Crustac. Biol., 5, 258-272, https://doi.org/10.2307/1547873, 1985.

McCormack, J.: McCormack et al._Biogeosciences_2019, Mendeley Data, v2, https://doi.org/10.17632/8bfshc85ww.2, 2019.

McCormack, J., Bontognali, T. R. R., Immenhauser, A., and Kwiecien, O.: Controls on Cyclic Formation of Quaternary Early Diagenetic Dolomite, Geophys. Res. Lett., 45, 3625-3634, https://doi.org/10.1002/2018GL077344, 2018.

McCormack, J., Nehrke, G., Jöns, N., Immenhauser, A., and Kwiecien, O.: Refining the interpretation of lacustrine carbonate isotope records: Implications of a mineralogyspecific Lake Van case study, Chem. Geol., 513, 167-183, https://doi.org/10.1016/j.chemgeo.2019.03.014, 2019a.

McCormack, J., Akdemir, D., Wrozyna, C., Kwiecien, O., and Viehberg, F.: The Quaternary ostracod fauna of the ancient soda lakes of Asia Minor with special emphasis on Lake Van (Turkey), in preparation, 2019b.

Meisch, C.: Freshwater Ostracoda of Western and Central Europe, in: Süßwasserfauna von Mitteleuropa, edited by: Schwoerbel, J. and Zwick, P., Akademischer Verlag Spektrum, Heidelberg, 522 pp., 2000.

Mesquita-Joanes F., Smith A. J., and Viehberg F. A.: The Ecology of Ostracoda Across Levels of Biological Organisation from Individual to Ecosystem: A Review of Recent Developments and Future Potential, in: Developments in Quaternary Sciences, vol. 17, edited by: Horne D. J., Holmes J. A., Rodriguez-
Lazaro J., and Viehberg F. A., Elsevier, Amsterdam, 15-35, https://doi.org/10.1016/B978-0-444-53636-5.00002-0, 2012.

Meyer, J., Wrozyna, C., Gross, M., Leis, A., and Piller, W. E.: Morphological and geochemical variations of Cyprideis (Ostracoda) from modern waters of the northern Neotropics, Limnology, 18, 251-273, https://doi.org/10.1007/s10201-016-0504-9, 2016.

Neale, J. W.: Ostracods and palaeosalinity reconstruction, in: Ostracoda in the Earth Sciences, edtited by: De Deckker, P., Colin, J. P., and Peypouquet, J. P., Elsevier, Amsterdam, 125-157, 1988.

NGRIP members, Andersen, K. K., Azuma, N., Barnola, J. M., Bigler, M., Biscaye, P., Caillon, N., Chappellaz, J., Clausen, H. B., Dahl-Jensen, D., Fischer, H., Flückiger, J., Fritzsche, D., Fujii, Y., Goto-Azuma, K., Grønvold, K., Gundestrup, N. S., Hansson, M., Huber, C., Hvidberg, C. S., Johnsen, S. J., Jonsell, U., Jouzel, J., Kipfstuhl, S., Landais, A., Leuenberger, M., Lorrain, R., Masson-Delmotte, V., Miller, H., Motoyama, H., Narita, H., Popp, T., Rasmussen, S. O., Raynaud, D., Rothlisberger, R., Ruth, U., Samyn, D., Schwander, J., Shoji, H., Siggard-Andersen, M.-L., Steffensen, J. P., Stocker, T., Sveinbjörnsdóttir, A. E., Svensson, A., Takata, M., Tison, J.-L., Thorsteinsson, T., Watanabe, O., Wilhelms, F., and White, J. W. C.: High-resolution record of Northern Hemisphere climate extending into the last interglacial period, Nature, 431, 147-151, https://doi.org/10.1038/nature02805, 2004.

North, S. M., Stockhecke, M., Tomonaga, Y., and Mackay, A. W.: Analysis of a fragmentary diatom record from Lake Van (Turkey) reveals substantial lake-level variability during previous interglacials MIS7 and MIS5e, J. Paleolimnol., 59, 119-133, https://doi.org/10.1007/s10933-017-9973-z, 2017.

Pickarski, N. and Litt, T.: A new high-resolution pollen sequence at Lake Van, Turkey: insights into penultimate interglacial-glacial climate change on vegetation history, Clim. Past, 13, 689-710, https://doi.org/10.5194/cp-13-689-2017, 2017.

Pickarski, N., Kwiecien, O., Djamali, M., and Litt, T.: Vegetation and environmental changes during the last interglacial in eastern Anatolia (Turkey): a new high-resolution pollen record from Lake Van, Palaeogeogr. Palaeocl., 435, 145-158, https://doi.org/10.1016/j.palaeo.2015.06.015, 2015a.

Pickarski, N., Kwiecien, O., Langgut, D., and Litt, T.: Abrupt climate and vegetation variability of eastern Anatolia during the last glacial, Clim. Past, 11, 1491-1505, https://doi.org/10.5194/cp11-1491-2015, 2015b.

Randlett, M. E., Bechtel, A., van der Meer, M. T., Peterse, F., Litt, T., Pickarski, N., Kwiecien, O., Stockhecke, M., Wehrli, B., and Schubert, C. J.: Biomarkers in Lake Van sediments reveal dry conditions in eastern Anatolia during 110.000-10.000 years BP, Geochem. Geophys., 18, 571-583, https://doi.org/10.1002/2016GC006621, 2017.

Reimer, A., Landmann, G., and Kempe, S.: Lake Van, eastern Anatolia, hydrochemistry and history, Aquat. Geochem., 15, 195222, https://doi.org/10.1007/s10498-008-9049-9, 2009.

Rosenfeld, A. and Vesper, B.: The variability of the sieve-pores in Recent and fossil species of Cyprideis torosa (Jones, 1850) as an indicator for salinity and palaeosalinity, in: Aspects of Ecology and Zoogeography of Recent and Fossil Ostracoda, edited by: Löffler, H. and Danielopol, D., Junk, The Hague, 55-67, 1977.

Ruiz, F., Abad, M., Bodergat, A. M., Carbonel, P., RodríguezLázaro, J., González-Regalado, M. L., Toscano, A., García, E. X., and Prenda, J.: Freshwater ostracods as environmen- 
tal tracers, Int. J. Environ. Sci. Technol., 10, 1115-1128, https://doi.org/10.1007/s13762-013-0249-5, 2013.

Smith, A. J.: Lacustrine ostracodes as hydrochemical indicators in lakes of the north-central United States, J. Paleolimnol., 8, 121134, https://doi.org/10.1007/BF00119785, 1993.

Smith, A. J. and Palmer, D. F.: The versatility of Quaternary ostracods as palaeoclimate proxies: comparative testing of geochemical, ecological and biogeographical approaches, in: Ostracoda as proxies for quaternary climate change, edited by: Horne, D., Holmes, J., Rodriguez-Lazaro, J., and Viehberg, F., Elsevier, Oxford, 183-203, https://doi.org/10.1016/B978-0-44453636-5.00011-1, 2012.

Steffensen, J. P., Andersen, K. K., Bigler, M., Clausen, H. B., DahlJensen, D., Fischer, H., Goto-Azuma, K., Hansson, M., Johnson, S. J., Jouzel, J., Masson-Delmotte, V., Popp, T., Rasmussen, S. O., Röthlisberger, R., Ruth, U., Stauffer, B., Siggaard-Andersen M.-L., Sveinbjörnsdóttir, A. E., Svensson, A., and White, J. W. C.: High-resolution Greenland ice core data show abrupt climate change happens in few years, Science, 321, 680-684, https://doi.org/10.1126/science.1157707, 2008.

Stevens, L. R., Djamali, M., Andrieu-Ponel, V., and de Beaulieu, J. L.: Hydroclimatic variations over the last two glacial/interglacial cycles at Lake Urmia, Iran, J. Paleolimnol., 47, 645-660, https://doi.org/10.1007/s10933-012-9588-3, 2012.

Stockhecke, M., Anselmetti, F. S., Meydan, A. F., Odermatt, D., and Sturm, M.: The annual particle cycle in Lake Van (Turkey), Palaeogeogr. Palaeocl., 333, 148-159, https://doi.org/10.1016/j.palaeo.2012.03.022, 2012.

Stockhecke, M., Kwiecien, O., Vigliotti, L., Anselmetti, F. S., Beer, J., Çağatay, M. N., Channell, J. E. T., Kipfer, R., Lachner, J., Litt, T., Pickarski, N., and Sturm, M.: Chronostratigraphy of the 600,000 year old continental record of Lake Van (Turkey), Quaternary Sci. Rev., 104, 8-17, https://doi.org/10.1016/j.quascirev.2014.04.008, 2014b.

Stockhecke, M., Sturm, M., Brunner, I., Schmincke, H. U., Sumita, M., Kipfer, R., Cukur, D., Kwiecien, O., and Anselmetti, F. S.: Sedimentary evolution and environmental history of Lake Van (Turkey) over the past 600000 years, Sedimentology, 61, 18301861, https://doi.org/10.1111/sed.12118, 2014a.

Suzin, A. V.: Ostracoda from tertiary deposits of the North Caucasus. Grozninskii Orlena Trudovogo Krasnogo Znameni Nephtrnoi Institut, 11-184, 1956 (in Russian).

Svensson, A., Andersen, K. K., Bigler, M., Clausen, H. B., DahlJensen, D., Davies, S. M., Johnsen, S. J., Muscheler, R., Parrenin, F., Rasmussen, S. O., Röthlisberger, R., Seierstad, I., Steffensen, J. P., and Vinther, B. M.: A 60000 year Greenland stratigraphic ice core chronology, Clim. Past, 4, 47-57, https://doi.org/10.5194/cp-4-47-2008, 2008.

Tomonaga, Y., Brennwald, M. S., Livingstone, D. M., Kwiecien, O., Randlett, M. È., Stockhecke, M., Unwin, K., Anselmetti, F. S., Beer, J., Haug, G. H., Schubert, C. J., Sturm, M., and Kipfer, R.: Porewater salinity reveals past lake-level changes in Lake Van, the Earth's largest soda lake, Sci. Rep., 7, 1-10, https://doi.org/10.1038/s41598-017-00371-w, 2017.

Tressler, W. L.: The Ostracoda of Great Slave Lake, J. Wash. Acad. Sci., 47, 415-423, 1957.

Tzedakis, P. C.: Seven ambiguities in the Mediterranean palaeoenvironmental narrative, Quaternary Sci. Rev., 26, 2042-2066, https://doi.org/10.1016/j.quascirev.2007.03.014, 2007.
Van der Meeren, T., Verschuren, D., Ito, E., and Martens, K.: Morphometric techniques allow environmental reconstructions from low-diversity continental ostracode assemblages, J. Paleolimnol., 44, 903-911, https://doi.org/10.1007/s10933-010-9463-z, 2010.

Van der Meeren, T., Ito, E., Verschuren, D., Almendinger, J. E., and Martens, K.: Valve chemistry of Limnocythere inopinata (Ostracoda) in a cold arid environment - implications for paleolimnological interpretation, Palaeogeogr. Palaeocl., 306, 116-126, https://doi.org/10.1016/j.palaeo.2011.04.006, 2011.

Van Harten, D.: Variable noding in Cyprideis torosa (Ostracoda, Crustacea): an overview, experimental results and a model from Catastrophe Theory, Hydrobiologia, 419, 131-139, https://doi.org/10.1023/A:1003935419364, 2000.

Vesper, B.: To the problem of noding on Cyprideis torosa (Jones, 1850), B Am. Paleontology, 65, 205-216, 1975.

Viehberg F. A. and Mesquita-Joanes F.: Quantitative Transfer Function Approaches in Palaeoclimatic Reconstruction Using Quaternary Ostracods, in: Ostracoda as Proxies for Quaternary Climate Change, Vol. 17, edited by: Horne, D. J., Holmes, J. A., Rodriguez-Lazaro, J., and Viehberg F. A., Elsevier, Amsterdam, 47-64, https://doi.org/10.1016/B978-0-444-536365.00004-4, 2012.

von Grafenstein, U., Eicher, U., Erlenkeuser, H., Ruch, P., Schwander, J., and Ammann, B.: Isotope signature of the Younger Dryas and two minor oscillations at Gerzensee (Switzerland): palaeoclimatic and palaeolimnologic interpretation based on bulk and biogenic carbonates, Palaeogeogr. Palaeocl., 159, 215229, https://doi.org/10.1016/S0031-0182(00)00086-9, 2000.

von Grafenstein, U., Erlernkeuser, H., and Trimborn, P.: Oxygen and carbon isotopes in modern fresh-water ostracod valves: assessing vital offsets and autecological effects of interest for palaeoclimate studies, Palaeogeogr. Palaeocl., 148, 133-152, https://doi.org/10.1016/S0031-0182(98)00180-1, 1999.

Wick, L., Lemcke, G., and Sturm, M.: Evidence of Lateglacial and Holocene climatic change and human impact in eastern Anatolia: high-resolution pollen, charcoal, isotopic and geochemical records from the laminated sediments of Lake Van, Turkey, The Holocene, 13, 665-675, https://doi.org/10.1191/0959683603hl653rp, 2003.

Wilkinson, I. P., Bubikyan, S. A., and Gulakyan, S. Z.: The impact of late Holocene environmental change on lacustrine Ostracoda in Armenia, Palaeogeogr. Palaeocl., 225, 187-202, https://doi.org/10.1016/j.palaeo.2005.06.010, 2005.

Wolff, E. W., Chappellaz, J., Blunier, T., Rasmussen, S. O., and Svensson, A.: Millennial-scale variability during the last glacial: The ice core record, Quaternary Sci. Rev., 29, 2828-2838, https://doi.org/10.1016/j.quascirev.2009.10.013, 2010.

Wrozyna, C., Frenzel, P., Daut, G., Mäusbacher, R., Zhu, L., and Schwalb, A.: Holocene lake-level changes of Lake Nam Co, Tibetan Plateau, deduced from ostracod assemblages and $\delta^{18} \mathrm{O}$ and $\delta^{13} \mathrm{C}$ signatures of their valves, in: Ostracoda as Proxies for Quaternary Climate Change, Vol. 17, edited by: Horne, D., Holmes, J., Rodriguez-Lazaro, J., and Viehberg, F., Elsevier, Amsterdam, 47-64, https://doi.org/10.1016/B978-0-444-536365.00016-0, 2012.

Xia, J., Ito, E., and Engstrom, D. R.: Geochemistry of ostracode calcite: Part 1. An experimental determination of oxygen isotope fractionation, Geochim. Cosmochim. Ac., 61, 377-382, https://doi.org/10.1016/S0016-7037(96)00351-1, 1997. 
Xu, H., Ai, L., Tan, L., and An, Z.: Stable isotopes in bulk carbonates and organic matter in recent sediments of Lake Qinghai and their climatic implications, Chem. Geol., 235, 262-275, https://doi.org/10.1016/j.chemgeo.2006.07.005, 2006.

Yin, Y., Geiger, W., and Martens, K.: Effects of genotype and environment on phenotypic variability in Limnocythere inopinata (Crustacea: Ostracoda), Hydrobiologia, 400, 85-114, https://doi.org/10.1023/A:1003759125903, 1999.
Zhang, J., Holmes, J. A., Chen, F., Qiang, M., Zhou, A., and Chen, S.: An 850-year ostracod-shell trace-element record from Sugan Lake, northern Tibetan Plateau, China: Implications for interpreting the shell chemistry in high-Mg / Ca waters, Quat. Int., 194, 119-133, https://doi.org/10.1016/j.quaint.2008.05.003, 2009. 